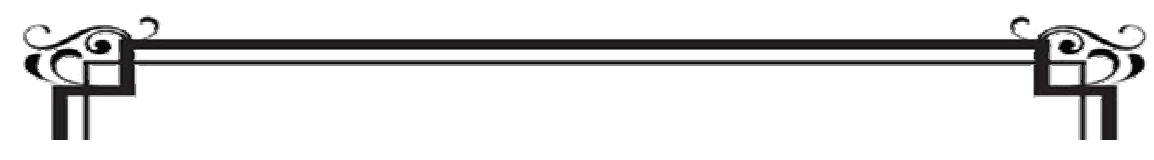

$$
\text { قَسم الشربعة }
$$

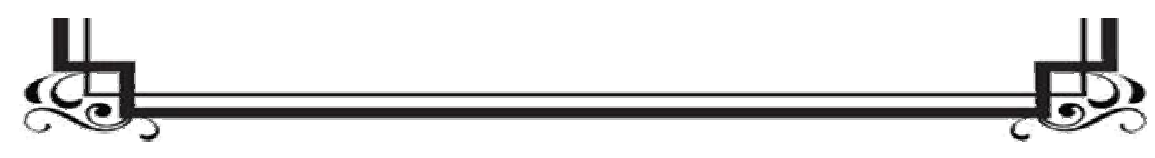





\title{
جراحات التجميل
}

"دراسة فقهية مقارنة"

\author{
إعداد \\ الدكتورة \\ ذسرين محمد محمد العزازي \\ مدرس الفقه المقارن \\ بكلية الدراسات الإسلامية والعربية \\ للبنات بالزقازيق
}





\section{ملخص البحث}

الحمد لله رب العالمين، و الصلاة و السلام على اثرف الأنبياء و المرسلين. أما بعد... (n)

فتعد الجراحات التجميلية من الجراحات الحديثة بسبب ما بطر أ عليها كل يوم من استحداث سواء في الأساليب أو طرق العلاج أو مواضع وأماكن التجميل؛ لذا

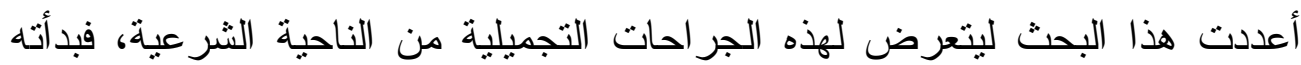
بمقدمة تتضمن سبب اختباري لهذا الموضوع، ثم أتبعته بتمهيد مبينة فيه حقيقة لفظ الجر احة و التجميل و العمليات الجراحية في اللغة والاصطلاح، ثم بمبحثين الأول: أنواع جر احات التجميل وحكمها، و الثاني: الضو ابط و التحذير ات الو اجب مر اعاتها عند إجر اء الجراحات التجميلية ثم أنهيته بخاتمة تشتمل على أهم ما توصلت إليه من نتائج خلال هذا البحث.

\section{$\underline{\text { Research Summary }}$}

Praise be to Allah, Lord of the Worlds, and peace and blessings be upon the most honorable prophets and messengers. Either after Cosmetic surgery is one of the most modern surgeries because of the daily developments in both methods, methods of treatment or places and places of beauty. Therefore, I prepared this research to expose these plastic surgery in terms of legitimacy. I started with an introduction that includes an optional reason for this subject. And cosmetic and surgical operations in language and terminology and then the first two: the types of plastic surgery and its rule, and the second: the controls and warnings to be taken into account when conducting plastic surgery and then ended with a conclusion containing the most important findings of this research. 
يتكون هذا الموضو ع من: مقدمة، وتمهيد، ومبحثين، وخاتمة

التمهيد: حقيقة لفظ الجر احة و التجميل و العمليات الجر احية.

المبحث الأول: أنو اع جر احات التجميل وحكمها.

المبحث الثاني : الضو ابط والتحذيرات الواجب مر اعاتها عند إجراء الجراحات التجميلية.

الخاتمة: وتشتمل على :أهم ما توصلت إليه من نتائج خلال هذا البحث 


\section{جراحات التجميل}

\section{مقدمة}

الحمد لله رب العالمين، و الصلاة و السلام على أثرف الأنبياء و المرسلين؛ نبينا محمد و على آله وصحبه أجمعين، ومن اتبعهم بإحسان إلى يوم الدين...

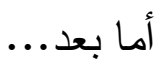

فإن الله تعالى خلق الإنسان في أحسن تقويم، فجعله في أفضل هيئة، و أكمل صورة، و أودع فيه غريزة التزيّن و التجمل، وما ز ال ذلك دأب الإنسان على مر العصور منذ الإن خلقه الله تعالى؛ خاصة المر أة لطبيعتها الأنثوية التي تتطلب عناية بالتزين و التجمل. ومع التقدم العلمي في شتى المجالات، ومنها المجال الطبي، بقيت هذه الرغبة تز اود الإنسان لا سيّما مع النطور السريع في مجال الجر احة الطبية؛ حيث أصبحت الجر احة التجميلية الحديثة بمجالاتها المختلفة أحد أهم فروع الجر احة الطبية، وصارت مقصدًا للر اغبين في الحُسن و الجمال دن الجنسين، و أصبح الكثيرون يتجهون إلى در اكز الجر احة التجميلية التي انتشرت بصور مذهلة. ومع الإقبال الو اسع على هذه المر اكز و المستتفيات المتخصصة تبرز الحاجة لدر اسة

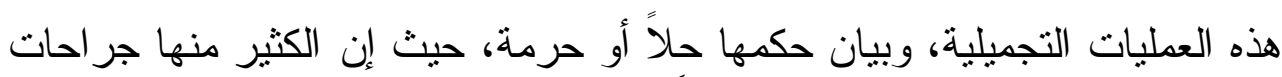
مستجدة لم يتم طرحها على بساط البحث الفقهي، فالموضوع يعد إحدى النوازل الفقهية في هذا العصر (')

(1) الجر احة التجميلية عرض طبي ودر اسة فقهية مفصلة، دكتور اصلح بن محمد الفوزان صده،

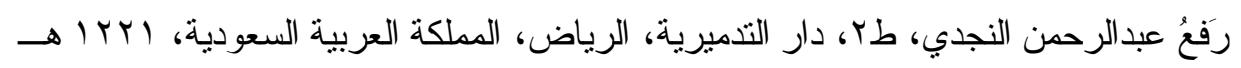




\section{جراحات التجميل}

\section{تمهـي}

حقيقة لفظ الجر احة، التجميل، الجر احات التجميلية. لابد قبل الخوض في غمار الجر احة التجميلية من الحديث عن حقيقة لفظ الج الجر احة، وكذلك أيضًا حقيقة لفظ التجميل، و المعنى المر اد من الجر احات التجميلية، وذلك على هي

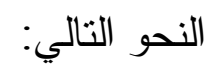

\section{أولاً: تعريف الجر احة:}

عند علماء اللغة:

الجر احة في اللغة أصلها الجيم، و الراء، و الحاء، ولهذه المادة أصلان كما ذكر (بن

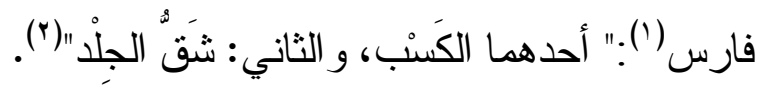

وقد فسر بعض أهل اللغة الجَرْحَ بالتأثنير في البدن بالسلاح، و الجر احة بأنها اسم

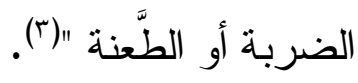

(1) (ابن فارس: هو أبو الحسين أحمد بن فارس بن زكريا القزويني، الإمام اللغوي المفسر ، أصــلـه

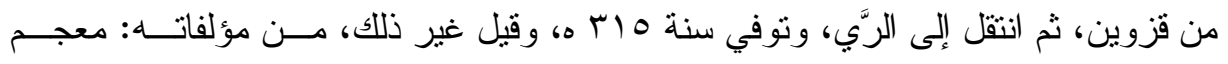

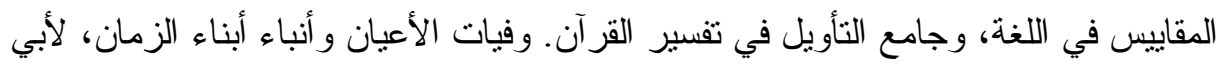

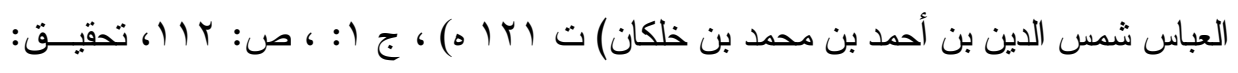

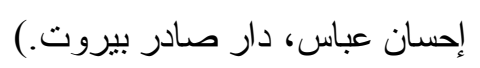

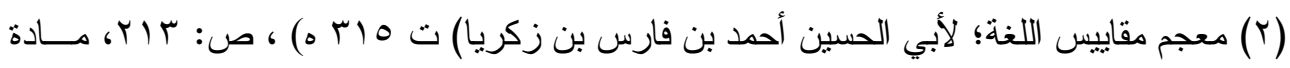

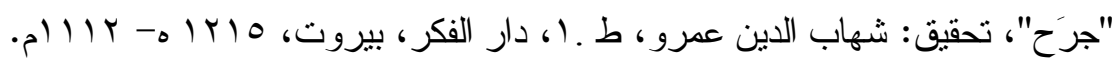

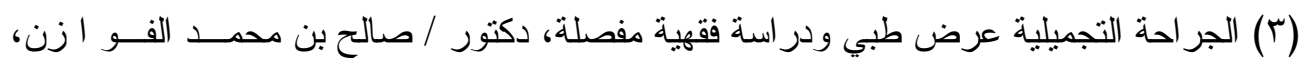

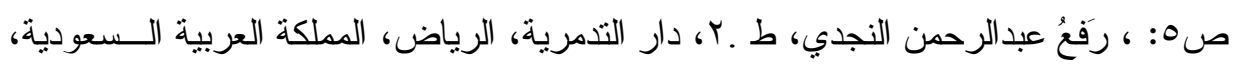

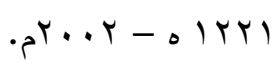


لكن المعنى الذي ذكره ابن فارس يبدو أكثر دقة، و أقرب للمجال الطبي المعاصر، فلابد من الإشارة إلى شق الجلد و البدن، ولذا فقد جاء في بعض المعاجم المعاصرة أن

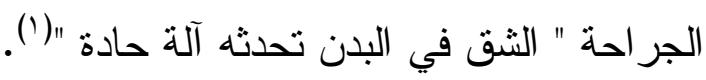

أما عند الأطباء: فالجر احة: فن من فنون الطب يعالج الأمراض بالاستئصال أو الإصلاح، أو الزراعة، أو غيرها من الطرق التي تعتمد كلها على الجرح، و الثق،

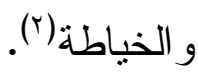

\section{تثانيا: تعربف التجمبل:}

أصل المادة الجيم، و الميم، و اللام، وقد قال ابن فارس: " و الجيم، و الميم، و اللام

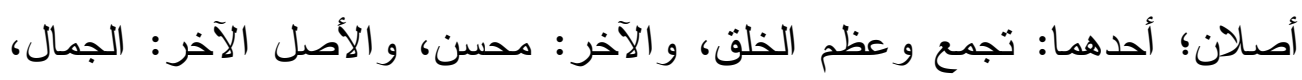

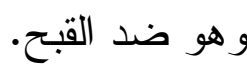

وقال ابن قتيبة(ץ): "أصله من التجميل، وهو وترك الثحم المذاب، يراد أن ماء السمن يجري في وجهه "(؛).

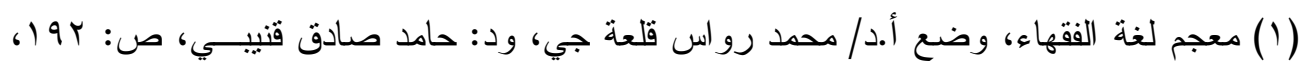

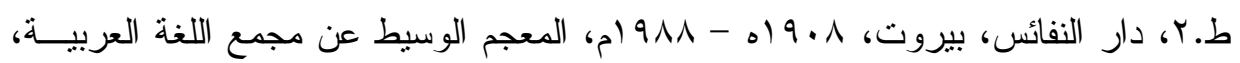

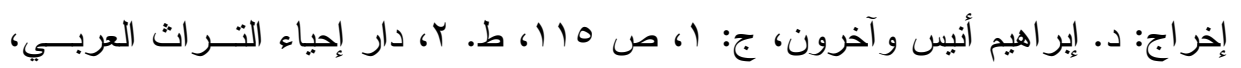

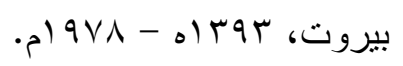

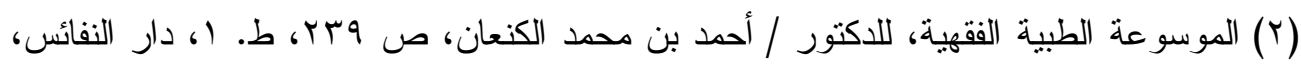

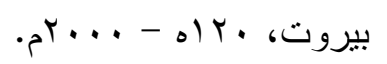

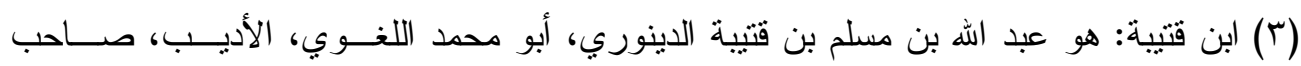

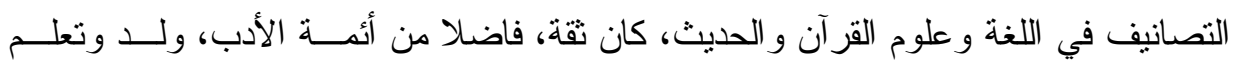

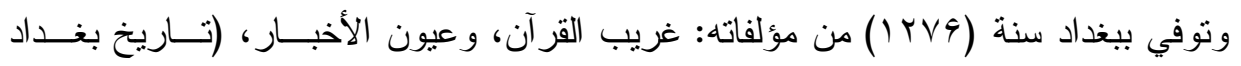

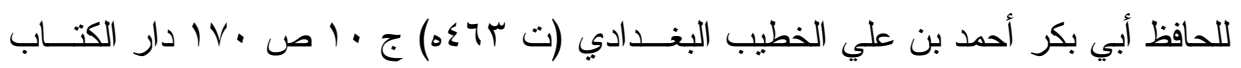
العربي بيروت.

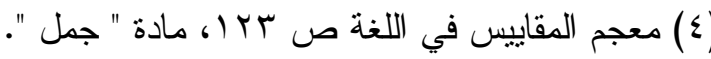
हिर्व 


\section{جراحات التجميل}

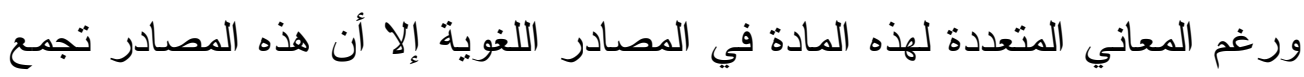

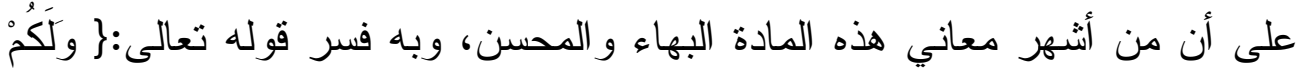

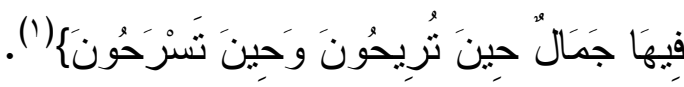
أي: بهاء وحسن، ويكون الجمال في الفعل و الخلق.

وقد عرفت بعض المعاجم المعاصرة التجميل بأنه: "عمل كل ما من شأنه تحسين

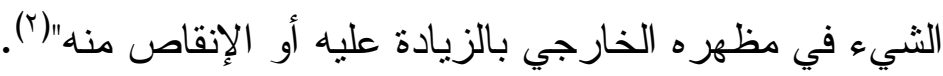

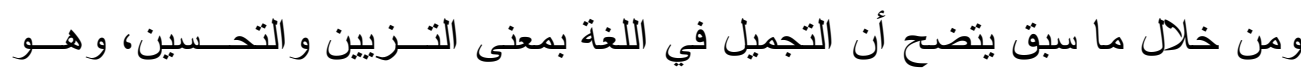
التصرف في البدن بما يؤول إلى البهاء و الوضاءة و الحسن في مظهره الخارجي. وهذا المعنى اللغوي للتجميل يتتاسب مع موضوع بحث الجر احسات التجميليــة لأن المر اد من التجميل في هذا المقام المعنى الحسي الذي يتعلق بقو ام الجسم وأعــضائه

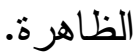

و إن كان لفظ الجمال بستعمل في الأمور الحسية و المعنوية(؟).

\section{ثالثا: تعريف الجراحة التجميلية:}

تعرف بعض الموسوعات الطبية الجراحة التجميلية بأنها: "إجراء طبي جراحي يستهذف تحسين مظهر ، أو وظيفة أعضاء الجمم الظاهرة"، وهذا التعريف يشتمل على عدة قيود تتمثل فيما يلي:

1." طبي ": قيد يخرج إجراءات التجميل غير الطبية؛ كتجميل الثعر بالوصل و القص، وتجميل الوجه بالأصباغ و الإضافات الصناعية، ونحو ذللك.

$$
\begin{aligned}
& \text { (1) لسان العرب، ج: 1)، ص: "זr|، مادة " جمل ". }
\end{aligned}
$$

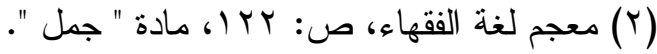

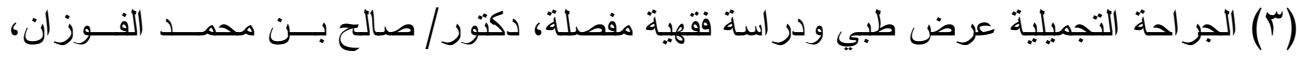

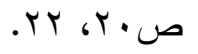




\section{جراحات التجميل}

r. "جراحي": قبد يخرج الإجر اءات الطبية غير الجر احية؛ كالمستحضر ات الطبية المختلفة التي ير اد منها علاج الجلد، وتجميل الوجه و غيره من أعضاء البدن؛ علما بأن المر اد بالجر احة المعنى العام الذي يقوم على شق الجلد بأي صورة،

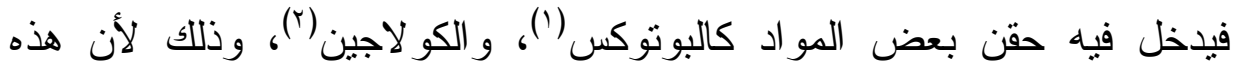
المو اد حقن عن طريق إبرة تشق الجلد، كما يدخل فيه استعمال شعاع الليزر ؛ لأنه يخترق الجلد، ويؤثر فيه، و لا ير اد المعنى الخاص الذي يقوم على استعمال المشرط، وحتى على هذا المعنى الخاص يمكن إدراج هذه الإجر اءات التجميلية لثهرتها عند جر احي التجميل، فهي ملحقة بهذا النوع من الجر احة.

r. "مظهر": إثنارة إلى الجر احات التجميلية التي ير اد منها تحسين مظهر أعضاء الجسم وتجميلها، ومع أن تحسين الوظيفة ملحوظ في هذا النوع إلا أن الهدف

( (1) حقن البوتوكس: هو عبارة عن بروتينات طبيعية من بكتيريا توجد بكثرة في التربة، ويـسـاهم

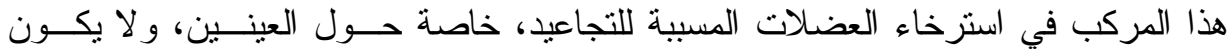

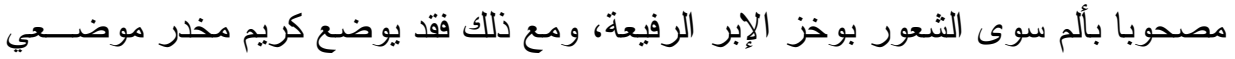

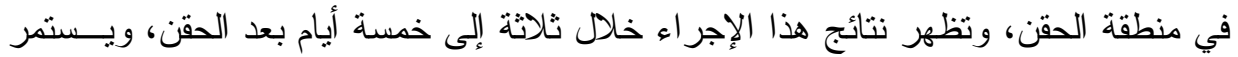

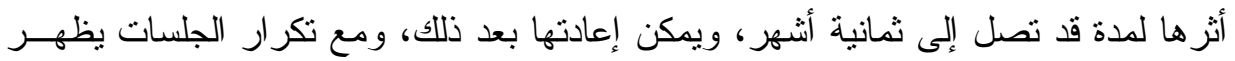

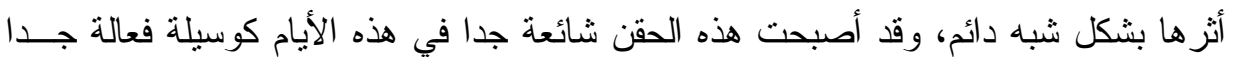
في الثقليل من التجاعيد، وتبرز فائدتها في منطقة الوجه و الرقبة لإضفاء مظهر أكثر شـــــابا، وحول العينين لإز الة التجاعيد، وخطوط العمر، وبين العينين لتغيير مظهر تقطيب الحاجبين، كما يمكن استخدامها في مناطق أخر من الوجه؛ كالذقن و الفكين. (دليل الجر احسـة التجميليــة

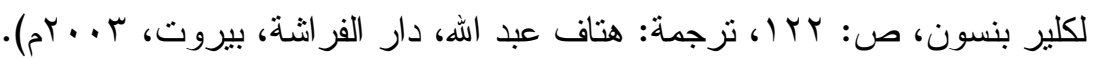

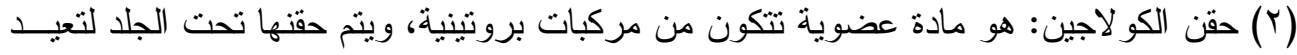

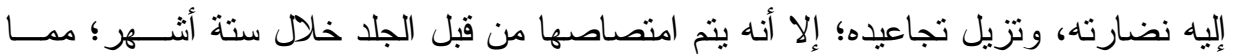
يستدعي إعادة الحقن للحصول على النتائج المرجوة، غير أنها تسبب الحساسية؛ لذا لابد مسن

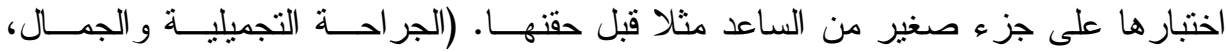

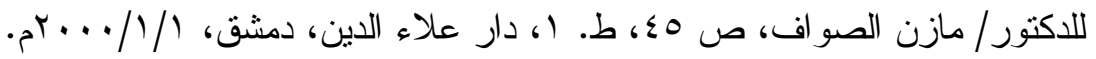




\section{جراحات التجميل}

الأصلي تحسين المظهر ، وهذا ما يعرف بالجراحة التجميلية التحسينية، فتجميل الأنف مثلا له غرض تجميلي من ناحية المظهر، وقد يكون فيه تحسين وظيفة التنفس.

؛. "وظيفة": إثنارة إلى الجراحات التجميلية التي ير اد منها تحسين الوظيفة ابتداء

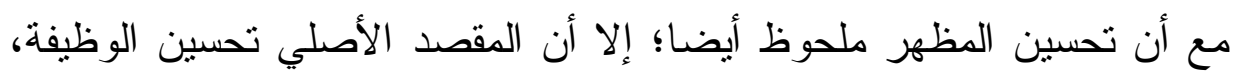

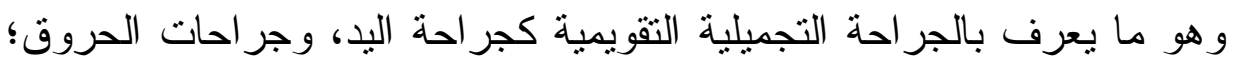
حيث يراد بهذه الجراحات تأهيل الأعضاء التي أصابها حادث ما، وتحسين بلهن وظيفتها مع العناية بمظهرها؛ إذ يحرص الأطباء على عودة الأعضاء المتأثرة

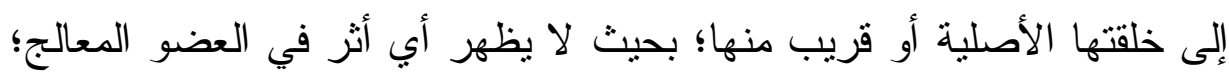

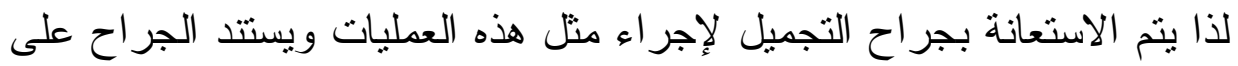

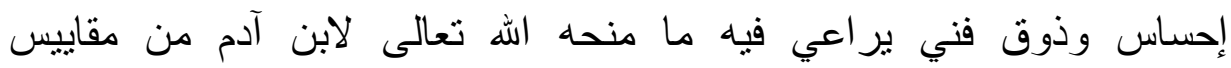

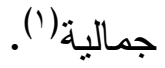

ه." الظاهرة ": قبد يدل على اختصاص الجراحة التجميلية بالأعضاء الظاهرة للجسم، ولذا تسمى هذه الجراحة: جراحة الجلا و الأنسجة الرخوة، وهذا قيد أغلبي لا لي؛ إذ أن جر اح التجميل قد بشارك غيره من الجر احين في إجراء بعض الجراحات الداخلية؛ إلا أن ذلك نادر مقارنة بما يجري على الأعضاء الظاهرة. ومن أنثهر أمتلة العمليات الداخلية التي يشارك فيها جر اح التجميل: ا. المساهمة في نقل جزء من الأمعاء إلى الرقبة والصدر لتعويض جزء من

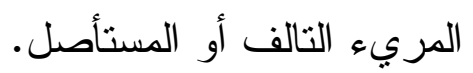
r. مساعدة جر اح التجميل في توصيل الأوعية الدموية أثناء زر اعة الكبد.

( (1) مقال "جر احة التجميل " للاكتور جمال جمعة، ص: . ع، مجلة المبنعث، العدد (100)، وزارة

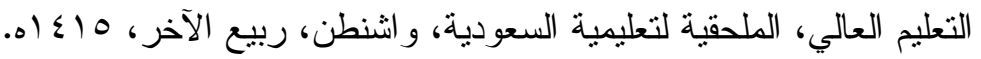


r. قيام جر اح التجميل بنقل عضلة الظهر إلى داخل القفص الصدري لعلاج

تقرحات الصدر أو لإحاطة القلب لدعم وظيفته أثناء ضخ الدم (').

(1) (1) كتاب: Maxil of acial and reconstructive surgery book of plastic (Text bعد

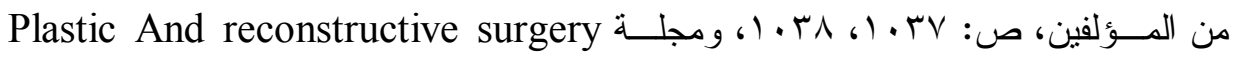

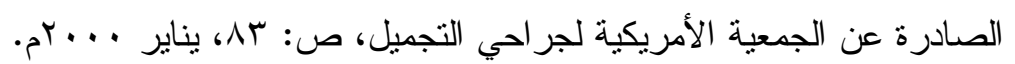




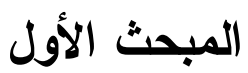

أنواع جراحات التجميل وحكمهيا

ويتكون هذا المبحث من مطالبين: المطلب الأول: جر احة تجميلية مشرو عة

المطلب الثاني: جر احة تجميلية محرمة (غير مشرو عة).

المبحث الأول

أنواع جراحات التجميل وحكمها

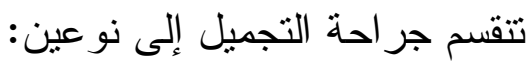
النوع الأول: جر احة تجميلية مشرو عة.

النوع الثاني: جر احة تجميلية محرمة (غير مشروعة) (').

وسوف أتعرض بإذن اله في هذا المبحث لهذين النوعين بشيء من التقصيل مع بيان

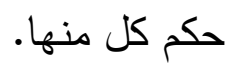

$$
\text { المطلب الأول }
$$

جراحة تجميلية مشروعة

و هذه الجر احة تتقسم إلى قسمين: - 20

القسم الأول: جر احة تجميلية بهدف التداوي و المعالجة الطبية.

القسم الثاني: جر احة تجميلية شهدت أدلة الثر ع بجو از ها.

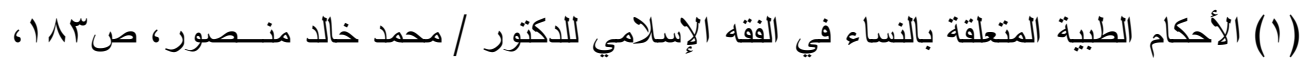

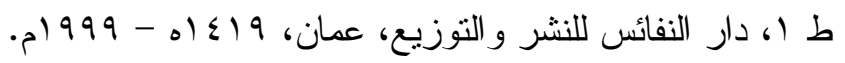
पिद्ध 
وسوف أتعرض لهذين القسمين بشيء من التقصيل على النحو التالي:

\section{القسم الأول}

\section{جر احة تجميلية بهدف التداوي والمعالجة الطبية}

وهي الجر احة التي يقصد منها: " التذاوي و المعالجة الطبية ".

و التي يمكن تقسيم الداعي لفعلها إلى سببين:

الأول: سبب ضروري، وهو جملة من الأسباب والموجبات التي يقصد بها: إزالة عيب في خلقه، أو تشوه، أو تلف، أو نقص؛ لتوفر الضرورة التي تحفظ بها النفس من الهلكة.

وذلك كبناء المثانة بالثر ائح العضلية؛ لأن المثانة جزء ضروري للتحكم في البول عن طريق الانقباض والانبساط في عضلاتها، وهو ضروري للإنسان، و إلا فلا يمكنه التحكم في البول، ويسبب ذللك وجود سلس في البول، وهو مؤد

\section{إلى نجاسة الثياب بصورة دائمة (').}

الثاني: سبب حاجي(؟): وهو جملة من الأسباب والموجبات التي يقصد بها: إزالة العيوب و التشوهات، وذلك لتوفر الحاجة التي تلحق بالمكلف ضرر ا حسيا أو

$$
\text { معنويا، و لا تصل إلى حد الضرورة الثر عية(؟). }
$$

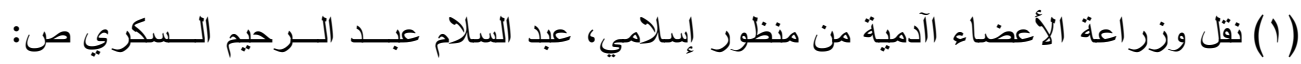

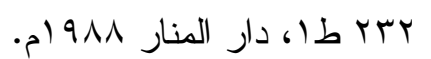

(Y) المرجع السابق، و أحكام الجر احة الطبية و الآثار المترتبة عليها، للاكتور محدد محمد المختــار

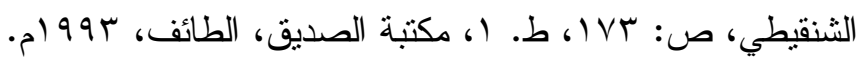

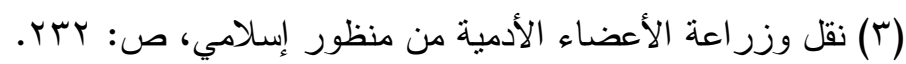




\section{جراحات التجميل}

و الأطباء يصفون هذه العمليات بكونها ضرورية(')، ولا يفرقون بين الضرورة، و الحاجة التي لا تبلغ مقام الضرورة؛ ذلك أنهم ينظرون إلبها بدافع الحاجة إلى لـ لهون فعلها.

كما أن وصف هذه الجراحة بكونها ضرورية، أو حاجية هو بالنسبة لدواعيه الموجبة لفعله، ووصفها بالتجميلي هو بالنسبة لآثار ها ونتائجهاب(؟). مما سبق يمكن القول بأن جراحة التجميل بهدف التداوي والمعالجة الطبية يقصد بها: إز الة العيوب الخلقية، و التثوهات، و الثين، و النقص الذي يصيب المر أة في جسمها، و إعادته ورده إلى أصل خلقتها التي خلقها عليها أحكم الحاكمين (r). وتتقسم العيوب التي تصيب جسم المر أة إلى قسمين: القسم الأول: عيوب خلقية(؛) بكسر الخاء.

و هي العيوب التي تتشأ في جسم المر أة بسبب منه، لا بسبب خارج عنه؛ سو اء ولدت بها، أو كانت ناتئة من الآفات و الأمر اض التي تصيب جسمها. ومن أمنتلة العيوب الخلقية التي تصيب جسم المر أة وولدت بها: ا ـ الشق في الثفة العليا " الثفة المفلوجة(॰).

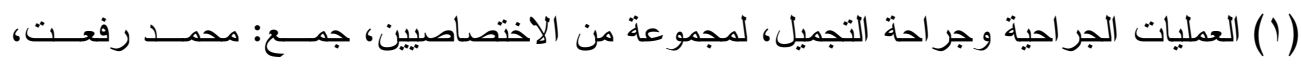

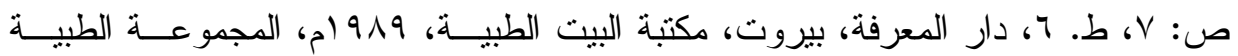

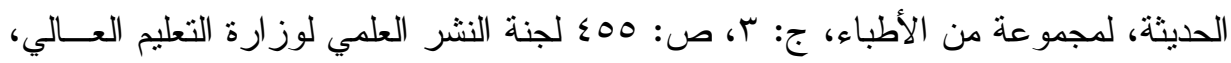

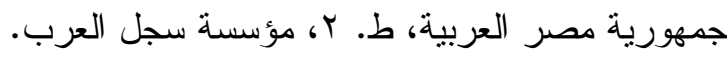

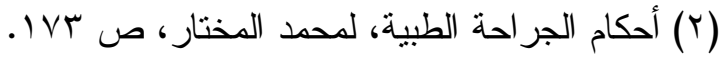

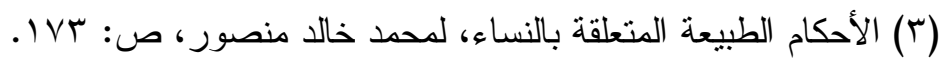

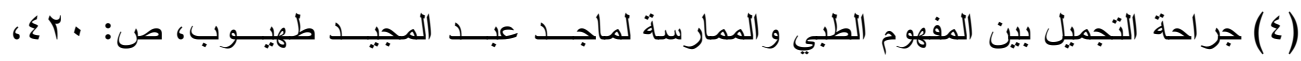

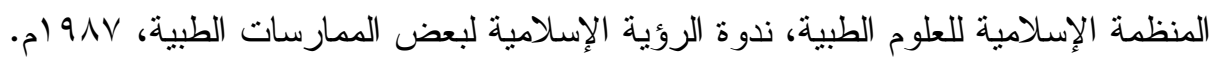

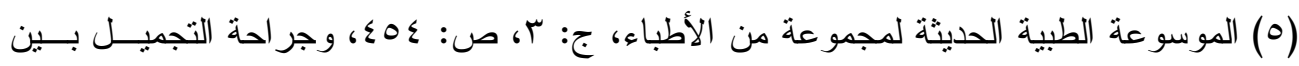

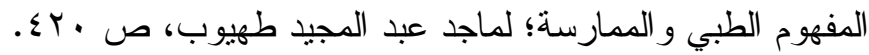


r. ظهور صيوان الأذن مفرطا أو كبير أو متضخما عن جدار الأذن؛ مما يــؤدي

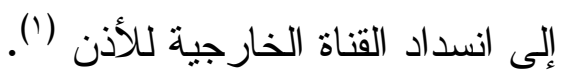

r. الثفة الأرنبة: وهي عاهة في الثفة العليا، وتكون فتحة الثفة فيها من جانب أو من جانبين، ومتوسط الثفتين كتلة من عظمة لحمية سميكة.

ومن أمتلة العيوب الخلقية التي تصيب المر أة بسبب مرض أو آفة بسبب داخلي:

ا ـ عيوب صيو ان الأذن بسبب ما يصيبه دن الأمر اض كالجذام أو السرطان(؟).

ץ- دو الي الساقين (r) الناشئة عن الوقوف طويلا أو الحمل (£).

القسم الثاني: عيوب طارئة (مكتسبة):

وهي العيوب الناشئة عن سبب خارجي؛ كالحو ادث و الحروق. ومن أمثلتها:

ا ـ تعويض جزئي أو كلي للأنف بسبب حادث أو صدمة، أو أنه قد استؤصل كجزء

من ورم (0) - (0)

r. الحروق المختلفة التي نتوه الجلد (؟).

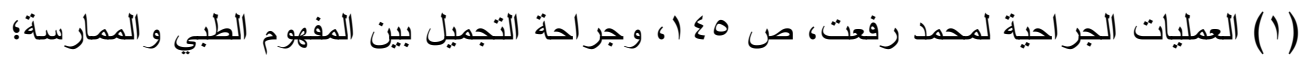

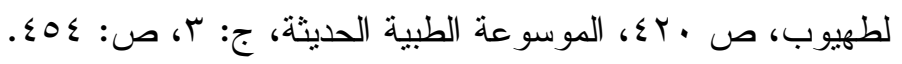

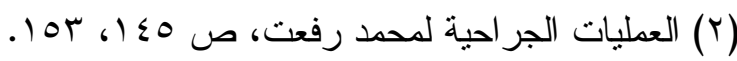

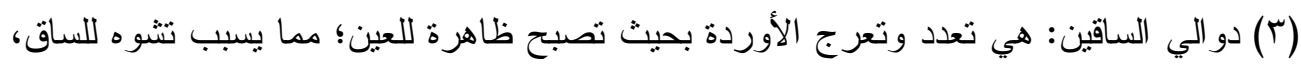

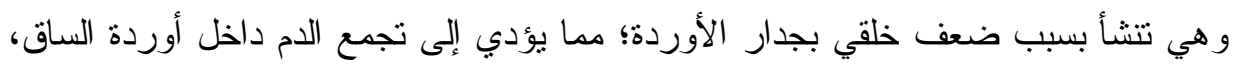
و أحيانا تحدث مضاعفات خطيرة لدو الي الساقين، وذلك يتجلط الدم داخل الأوردة المتعرضة.

$$
\begin{aligned}
& \text { (العمليات الجر احية لمحمد رفعت، ص: هـ). }
\end{aligned}
$$

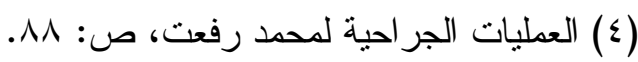

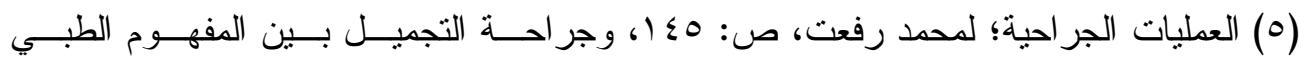

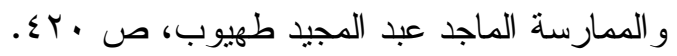

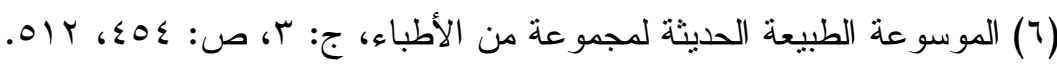


r. فقد جزء من الثفة بسبب حادث (').

ـ. زو ال شعر الر أس بحادث أو مرض(؟).

حكم الجراحة التجميلية بهدف التداوي والمعالجة الطبية:

ولما كان هذا النوع من الجراحة الطبية يقصد به التداوي و المعالجة الطبية، فإنه يجوز للطبيب فعلها، وللمريضة تعاطيها (r)، وذلك بما يتفق مع شروط جواز فعل بل الجر احة الطبية، و التي تتمنل فيما يلي: ا ـ أن يكون المريض محتاجا إليها:

لابد لجواز فعل الجراحة الطبية أن يكون المريض محتاجا إليها؛ سو اء كانت حاجة ضرورية يخاف منها ذهاب نفس أو عضو من أعضاء جسده، أو كانت حاجة دون ذلك؛ بأن بلغت مقام الحاجيات التي يلحقه بها الضرر البالغ بسبب آلام الأمراض

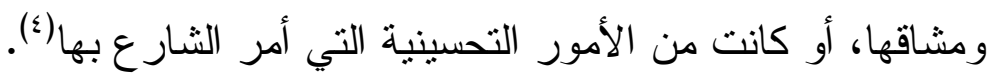
r. أن يأذن المريض أو وليه بفعل الجراحة:

يشترط لجواز فعل الجر احة الطبية أن يأذن المريض بفعلها إذا تو افرت فيـــه أهليـــة الأذن. أما إذا لم يكن أهلا، فإنه يعتبر إذن وليه؛ كأبيه، و أخيه مثنا. r. أن تثوافر الأهلية في الطبيب الجراح ومساعديه:

يشترط للطبيب الجر اح ومساعديه أن يكونو ا أهلا للقيام بالجر احة الطبية (0)، و أدائها

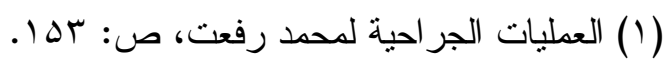

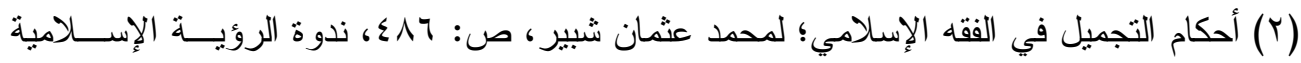

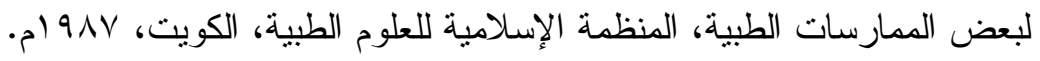

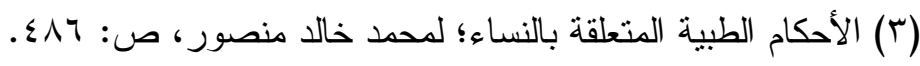

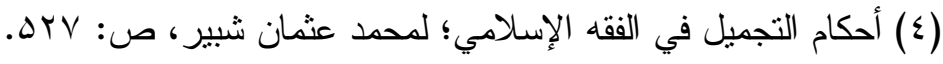

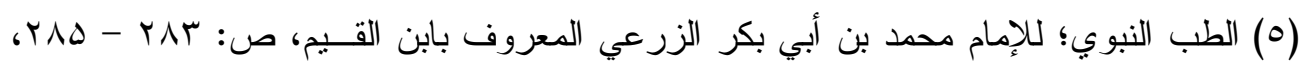

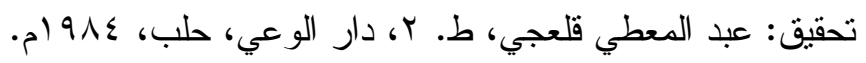


على الوجه المطلوب. و أهلية الطبيب الجر اح مشتملة على أمرين: الأول: أن يكون ذا علم وبصيرة بالمهمة الجر احية المطلوبة. الثاني: أن يكون قادر ا على تطبيقها، و أدائها على نحو يحقق الثفاء ('). ع. أن يغلب على ظن الطبيب الجراح نجاح العملية: يشترط لجواز فعل الجر احة الطبية أن يغلب على ظن الطبيب الجراح نجاح العملية، وتحقيق المقصود منها.

أما إذا غلب على ظنه عدم نجاحها، أو أنها ستؤدي إلى هلاك نفس أو عـضـ مــن جسد المريض، فلا يجوز لله عندئذ القيام بفعلهاب(؟).

وقد دلت النصوص الثرعية على اعتبار هذا الثرط، فمن ذلك قولــهـ تعــالى: روَّلا

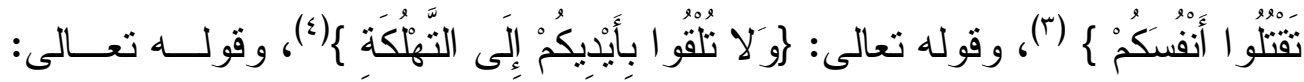

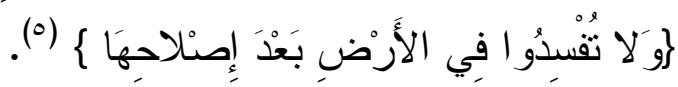

فالآيات الكريمة نص في النهي عن قتل النفس، و القائها في الهلكة، و الإفساد في الأرض بغير حق، وكل هذه المعاني منو افرة في إقدام الطبيب الجراح على فعل ولَ جر احة يغلب على ظنه فيها هلاك المريض، أو تضرره بتلف عضو من هن أعضاء

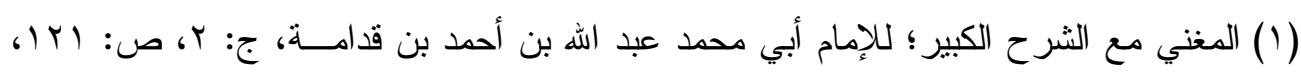
دار الكتاب العربي.

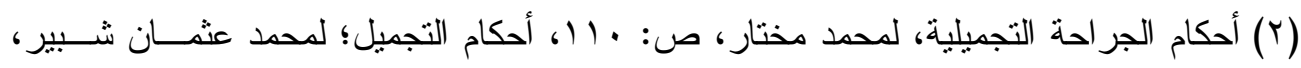
ص: OYV.

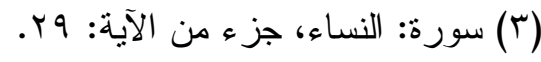

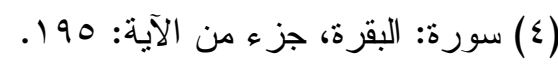
(0) سورة: الأعر اف، جزءة هن من الآية: 07. 
مما يشترط لجواز فعل الجراحة الطبية ألا يوجد البديل الذي هو أخف ضرر ا منها، فحيثا تمكن الطبيب الجراح من الوصول إلى العلاج بالأخف و الأسهل كالأغذية،

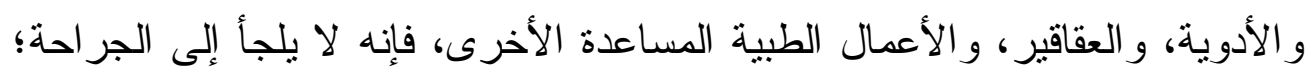
لأن تلكم الوسائل أخف ضررا منها؛ لما يلحق بها من مخاطر وأضر ار قد نودي بحياة المريض (1) - (1)

\section{7. ألا يترتب على فعلها ضرر أكبر من ضرر المرض:}

ومما يشترط لجواز فعل الجراحة الطبية ألا يترتب على فعلها ضرر أعظم من ضرر المرض (Y)؛ لأن " الضرر لا لايز ال بمنله "(r). أما إذا كان استخدام الجراحة مؤديا إلى تحقق المقصود بإز الة المرض؛ مع أمن وقوع ضرر أكبر ، فإنه يشرع فعلها؛ لأنه: " إذا تعارضت مفسدتان روعي أعظمها

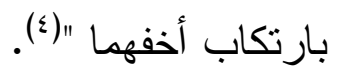

وقد نص مجمع الفقه الإسلامي الدولي المنبثق عن منظمة المؤتمر الإسلامي على جو از إجر اء الجر احة التجميلية الضرورية و الحاجية التي يقصد منها:

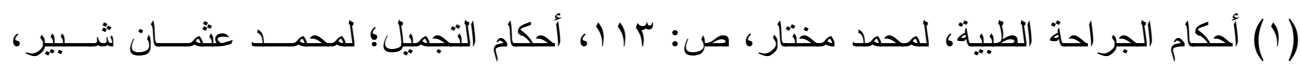
ص: OrV.

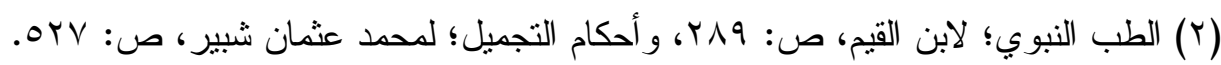

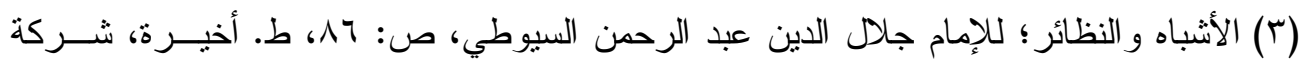
ومطبعة مصطفى البابي الحلبي، 909 ام.

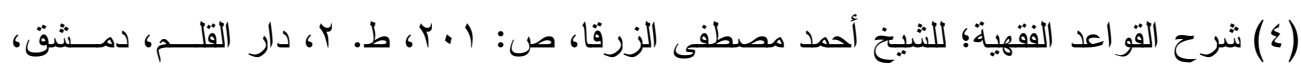
$\cdot$. 1919 


\section{جراحات التجميل}

أ. إعادة شكل أعضاء الجسم إلى الحالة التي خلق الإنسان عليها؛ لقوله

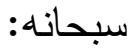

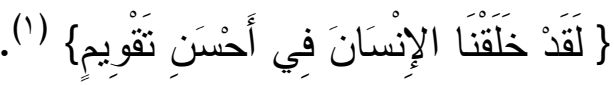
ب. إعادة الوظيفة المعهودة لأعضاء الجسم. ج. إصلاح العيوب الخلقية. د. إصلاح العيوب الطارئة "المكتسبة". ه. إز الة دمامة تسبب للثخص أذي نفسيا أو عضويا (؟). الأدلة الشرعية الدالة على جواز التداوي والمعالجة الطبية: استدل على جواز التذاوي و المعالجة الطبية بالجراحة التجميلية بأدلة من السنة

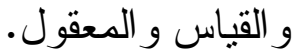

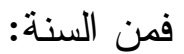
أ. حديث أبي هريرة عنه عن النبي أنه قال: [ ما أنزل اله من داء إلا وأنزل له

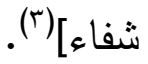

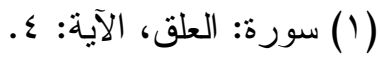

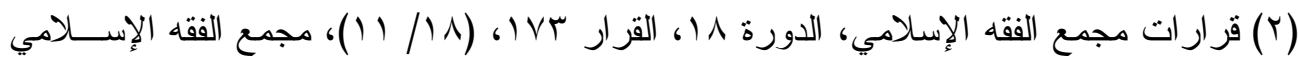
الدولي المنبثق عن منظمة المؤتمر الإسلامي، الدورة الثامنة عشرة.

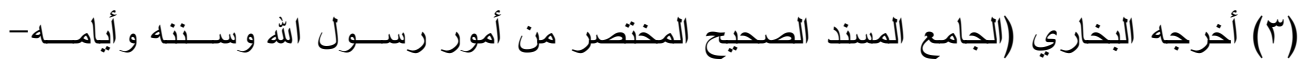

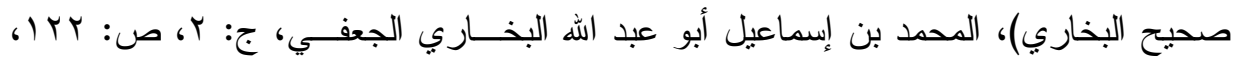
كتاب: الطب، باب: ما أنزل الله داء إلا أنزل له شفاء، رقم: OTVA، المحقق: محمد زهيـر

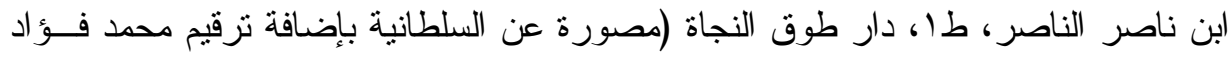

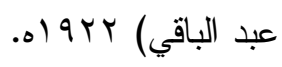


ب. حديث أسامة بن شريك (') نبإنه: وفيه: [ تداوو ا، فإنه الله لم يضع داء إلا وضع

$$
\begin{aligned}
& \text { له دو اء؛ غير داء واحد: الهرم][؟). } \\
& \text { وجه الدلالة من الحديثين: }
\end{aligned}
$$

إن المر اد من حديث النبي أن الله تعالى لم يوجد، ولم يخلق مرضا من الأمر اض

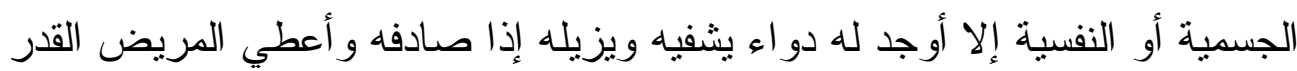
المناسب في الوقت، ولذا أمر النبي بالتداوي (r). الحديثان دالان على جواز التذاوي و المعالجة الطبية من سائر الأمر اض، وما ذكــر من الأمر اض في جر احة التجميل بقصد التداوي داخل في هذا الجواز؛ سواء أكــان السبب الداعي له ضروريا أم حاجيا(ع).

(1) أسامة بن شريك: هو أسامة بن شريك الثعلبي الذبيان، من بني ثعلبة بن سعد، ويقال: من بني

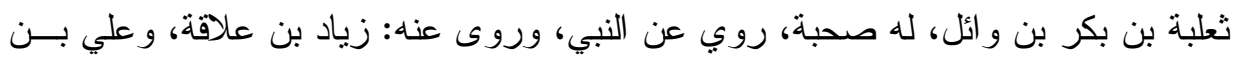

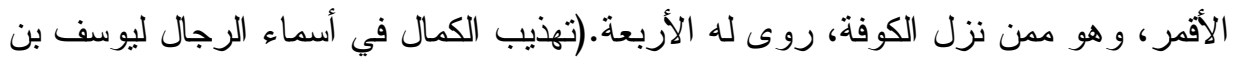

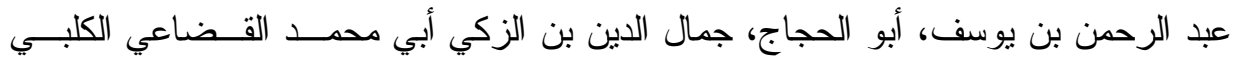

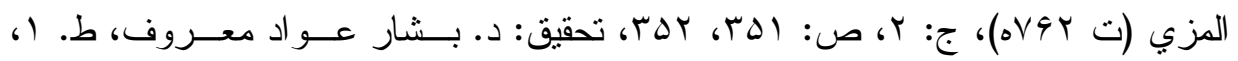

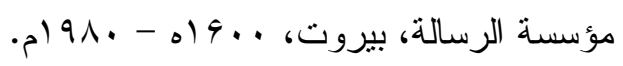
(Y) أخرجه الترمذي، وقال: هذا حديث حسن صحيح. (سنن الترمذي؛ لمحمد بن عيسى بن سؤرة

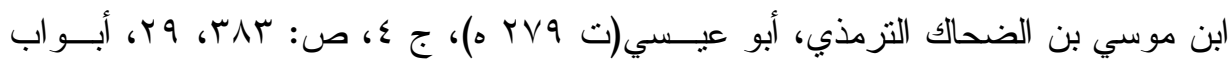

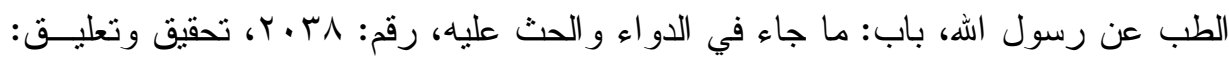

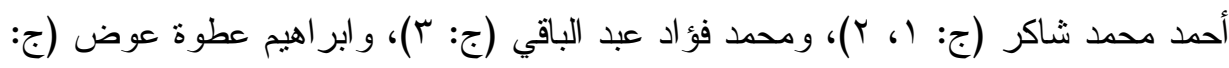

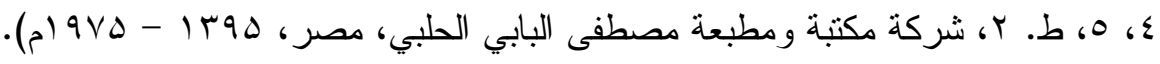

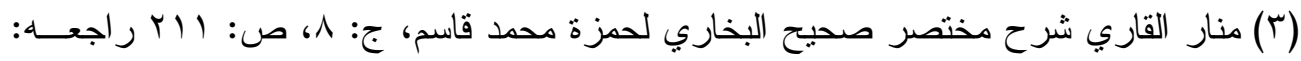

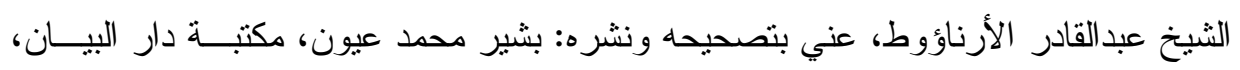

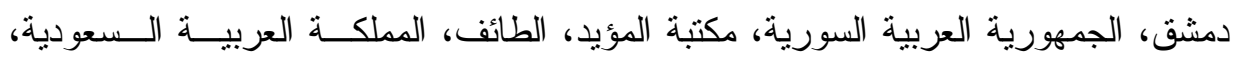

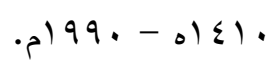

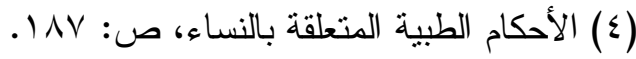




\section{جراحات التجميل}

ومن القياس:

ا ـ قياس جر احة التجميل بقصد التداوي على جواز القطع الذي نص الفقهــاء علــى

$$
\text { جوازه بجامع وجود الحاجة في كل('). }
$$

r. قياس الجر احة التجميلية على الجر احة العلاجية المشروعة بجامع وجود الحاجــة

$$
\text { لإجر اء كلا النوعين (r). }
$$

\section{من المعقول:}

ا. إنه يجوز فعل الجر احة الطبية إذا وجد سبب مبيح لفعلها، وجر احــة التجميـلـ بقد التداوي داخلة فيها لوجود الحاجة في كل منهما (ץ). r. إن هذه العيوب تتضمن ضرر ا حسيا ومعنويا(£)، وهو موجب للترخيص بفعـل

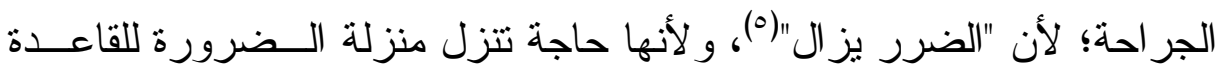
الفقهية القائلة بأن " الحاجة تنزل منزلة الضرورة عامة كانت أو خاصة"(؟). r. إن في ترك التداوي في منل هذه الحالات مشقة وعنا، و الثريعة الإسلامية قائمة على اليسر، ودفع المشقة عن المكلف، وذللك للقاعدة الفقهية التي تـنص علـى تلى

(1) قو اعد الأحكام في مصالح الأنام؛ للإمام العز بن عبد السلام، ج: (، ص: ^ \، دار المعرفة، بيروت. (Y) الموسوعة الميسرة في فقه القضايا المعاصرة (قسم فقه الأسرة)، إعداد مركز التميز البحثي

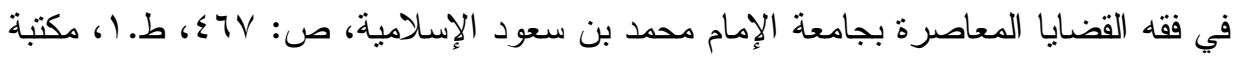

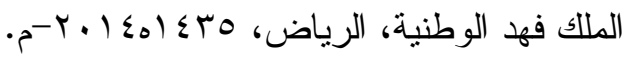

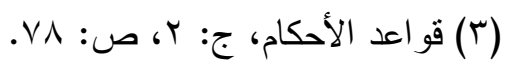

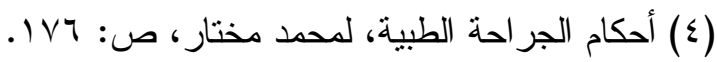

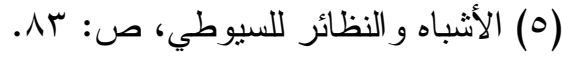

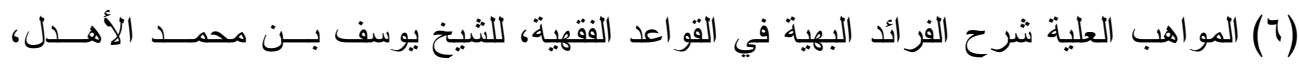

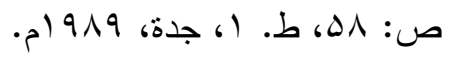


أن: " المشقة تجلب التيسير (').

ـ. إنه لا يعتبر التذخل الجر احي في منل هذه الحالات تغيير ا للخلقة الإلهيــة التـي دلت النصوص الثرعية على تحريم المساس بها، وذلك لما يأتي:

أ. إن هذا النوع من الجر احة وجدت فيه الحاجة الداعية للتغيير، فأوجبت اســتثناءه

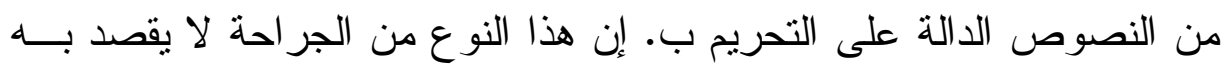
تغيير الخلقة عمدا، إنما يقصد به التداوي و التجميل جاء تبعا (؟). وبناء عليه، فإنها يشر ع للطبيب الجر اح وللمريضة إجــر اء عمليــات التجميـلـ

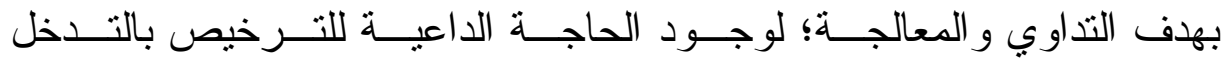
الجر احي (r). - (بن

(7) الأتباه و النظائر ، للسيوطي، ص: זی

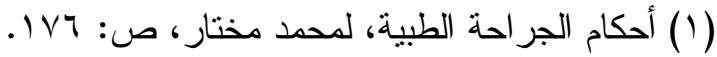

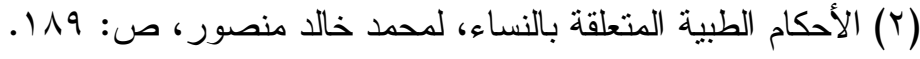

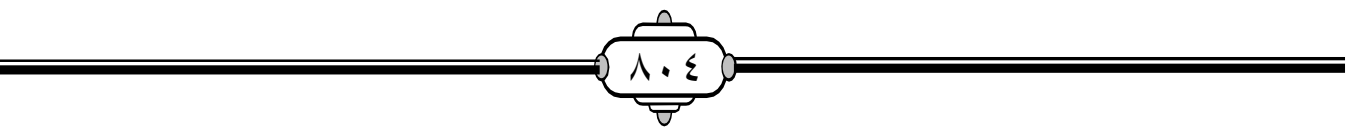




\section{القتسم الثاني}

\section{جر احة تجميلية شهدت أدلة الثرع بجوازها}

و هي تتضدن المسألثين التاليتنين:

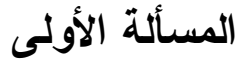

حكم ثقب (1) أذن الأثثى

اختلف الفقهاء في حكم ثقب أذن الأنثى للحلي على قولين:

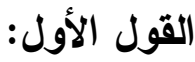

يجوز تقب أذن الأنثى للحلي (؟).

و هذا المذهب عند الحنفية(ז)، و الصحيح من مذهب الحنابلة، وهو القول الأول

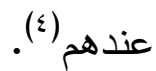

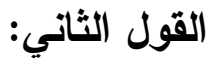

لا يجوز ثقب أذن الأنثى للحلي (०).

(1) الثقب: الخرق النافذ. القاموس المحيط؛ للإمام محمد بن يعقوب الفيـروز آبــادي، ص: اله،

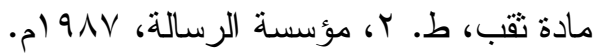

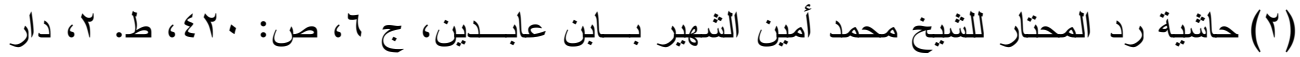
الفكر ، 977 ام، و الإنصاف في معرفة الراجح من الخلاف؛ للإمام علي بن سليمانالمرداوي، إن،

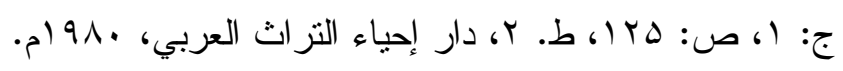

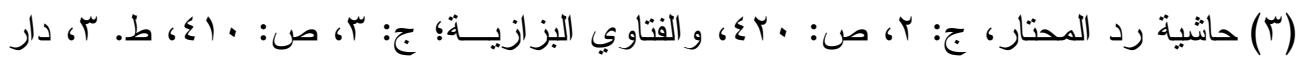

$$
\text { إحياء التزاث، بيروت، لبنان. }
$$

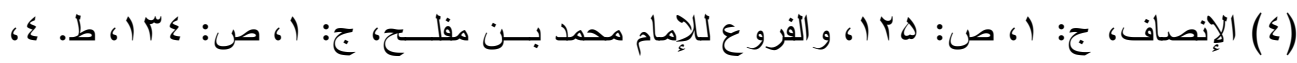

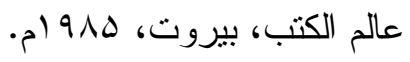

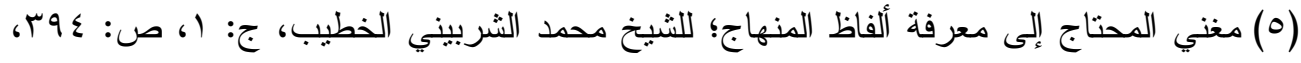

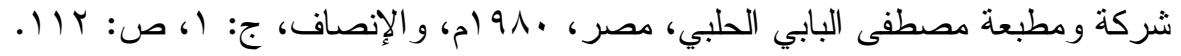




\section{جراحات التجميل}

وهذا المذهب عند الثافعية(')، ورو اية عند الحنابلة، و القول الثاني عندهم).

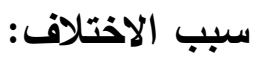

يرجع سبب اختلاف الفقهاء في حكم ثقب أذن الأنتى إلى الجواز، و عدم الجواز إلى اختلافهم في اعتبار ثقب أذن الأنتى مشابها للوشم، وتغيير الخلق الله أم لا؟ فمن رأى أنه لا يشبه الوشم وليس فيه تغيير الخلق الله، قال بالجواز ومن رأى أنه مشابها للوشم، وفيه تغيير الخلق اله قال بعدم الجواز (؟). الأدلة: أدلة القول الأول (الجواز):

استدل أصحاب القول الأول القائلون بالجو از على ما ذهبو إليه بالسنة، و المعقول: فمن السنة:

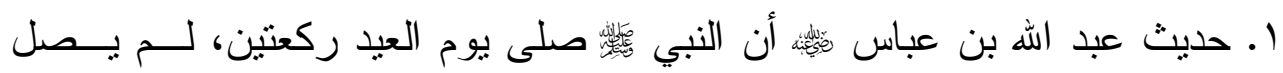
قبلهما و لا بعدهما، ثم أتى النساء ومعه بلال، فأمر هن بالصدقة، فجعلت المــر أة

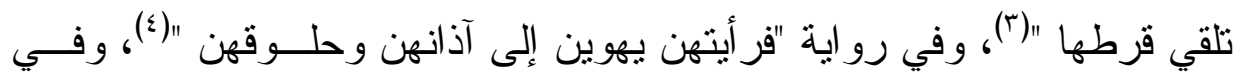

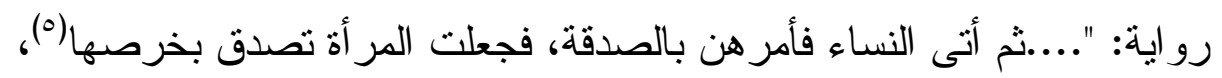

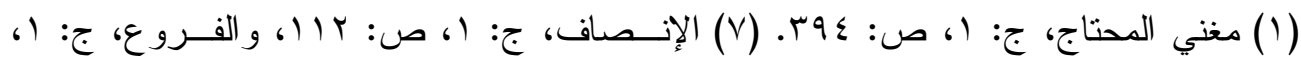
ص: عזו.

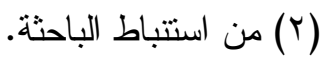

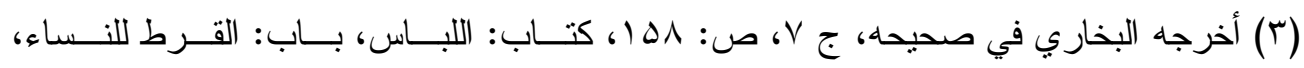

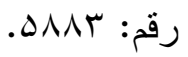

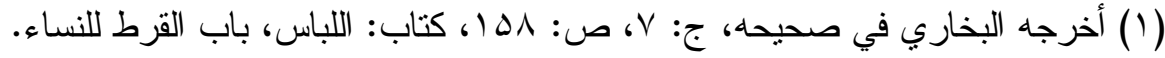

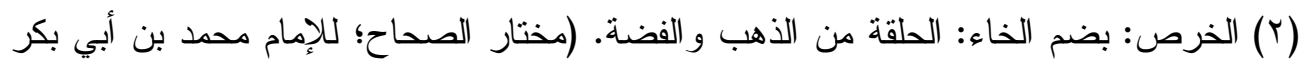

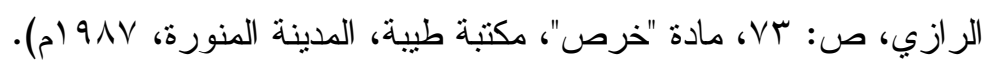




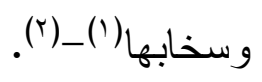

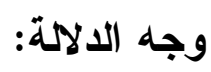

إن النبي

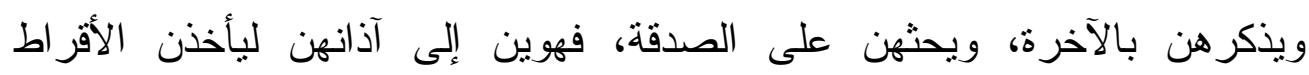

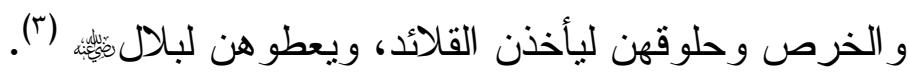
فالخرص هو الحلق الموضوع في الأذن بدليل الرواية: "... يهوين إلى آذانهن... ". فدل الحديث على أن ثقب الأذن كان موجودا في عهد النبي، ولو كان حر اما لنهى عنه، فعدم النهي بدل على جوازه(؛). اعتر اض على هذا الاستدلال:

بأنه يجوز أن تكون آذانهن قد ثقبت قبل مجيء الثرع، فيغتفر في الدوام ما لا يغتفر في الابتداء (0).

(1) السخاب بالسين المكسورة: قلادة من قرنفل ومحلب بلا جوهر . القاموس المحــيط، صس ب ا،

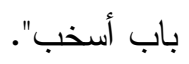

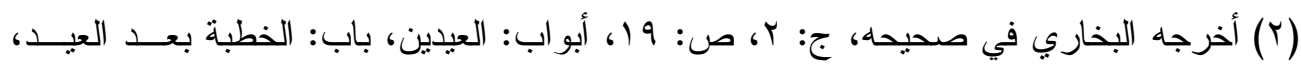
رقم: 97.

(r) إرشاد الساري لشرح صحيح البخاري؛ لأحمد بن محمد بن أبي بكر بن عبد الملك القسطلاني

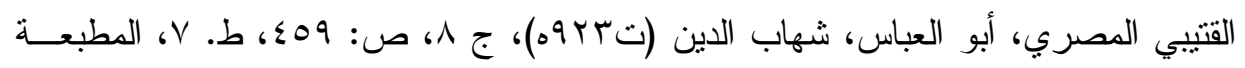

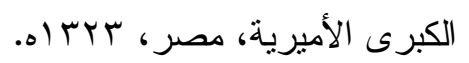

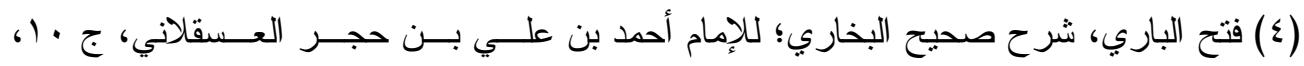
ص: اسبا، تصحيح: الثيخ عبد الله بن باز ، وترقيم: محمد فؤاد عبد الباقي، دار المعرفة.

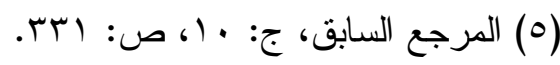




\section{جراحات التجميل}

\section{وأجيب عنه:}

بأنه لو كان محرما لنهى عنه النبي، فسكوته يدل على جو ازه، ولو كان خرم بعد لنبه النبي الصحابة على ذلك، ومعلوم أن تأخير البيان عن وقت الحاجة لا يجوز ('). r. حديث أم زرع: أنها قالت: زوجي أبو زرع، فما أبو زرع ؟ أناس(r) من حلي

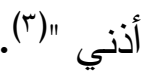

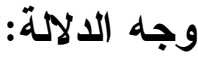

إن المر اد من الحديث أن زوج أم زر ع كان يملا أذنيها بما جرت به عادة النساء من التحلي به من القراريط وغيرها، و التحلي بالقر اط يدل على أنه كان هناك ثقب في

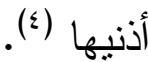

فالحديث يدل على علم النبي بثقب الأذن، وتعليق الحلي فيها للزينة، ولو كان محرما لأنكره النبي، فدل على جوازه(ه).

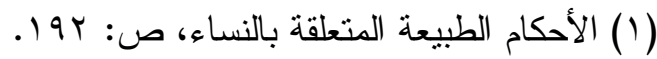

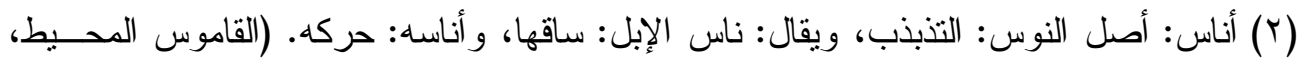

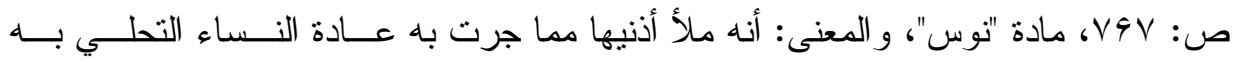

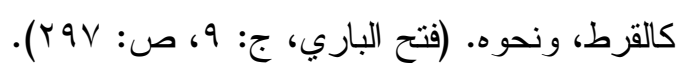

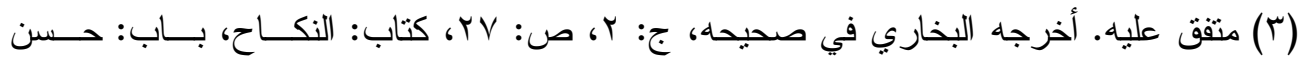

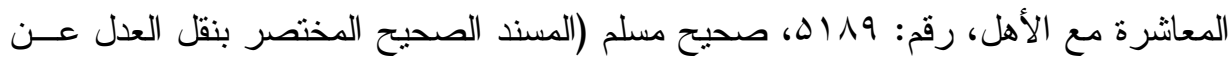

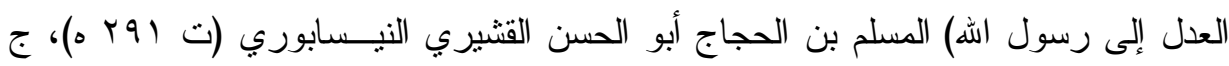

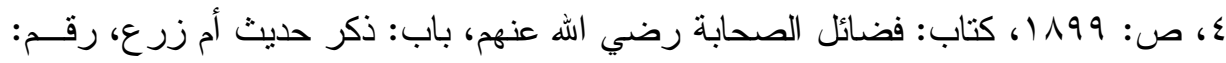

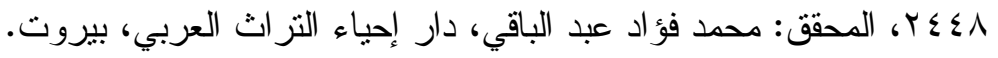

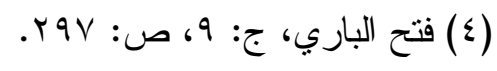

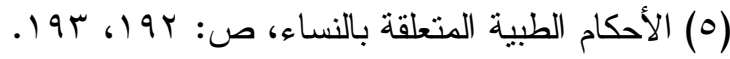




\section{جراحات التجميل}

\section{ومن المعقول:}

إن الأنثى محتاجة للنقب من أجل التحلي، وهو مصلحة في حقها، فجاز لها فعله('). أدلة القول الثاني (عدم الجواز): استذل أصحاب القول الثاني القائلون بعدم الجواز على ما ذهبوا إليه بالقياس، و المعقول: فمن القياس:

قياس ثقب أذن الأنثى على الوشم(ץ) بجامع وقوع الأذى في كل (r). وأعترض على هذا الاستدلال: بأنه قياس مع الفارق من جانبين:

الأول: أن الأذى المترتب على ثقب الأذن أخف من الأذى الناتج عن الوشج؛ بل إنه

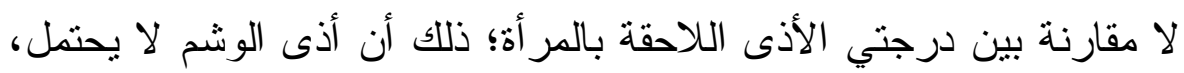
بخلاف أذي ثقب الأذن.

الثاني: أن في الوشم تغيير الخلق الله، وعبثا بالنفس الإنسانية بلا حاجة، و لا مسوغ، بخلاف ثقب أذن الأنتى، فإنه فعل يقصد به التزين الذي شهدت أدلة الشرع

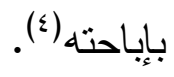

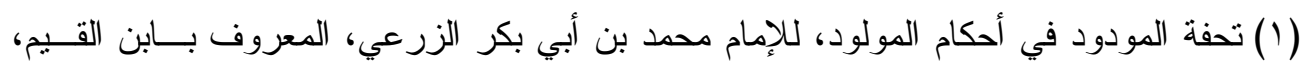

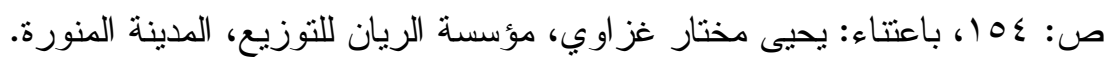

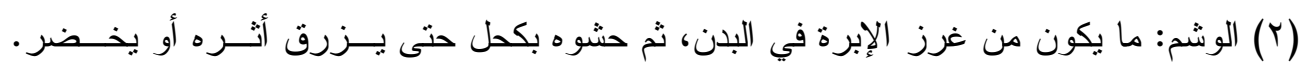

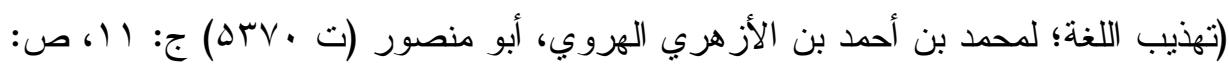

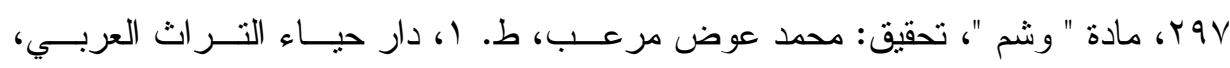

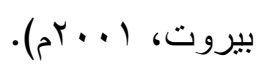

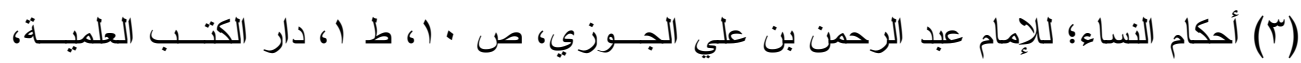

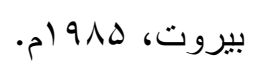

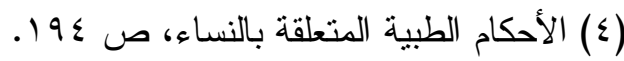




\section{جراحات التجميل}

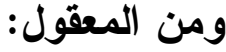

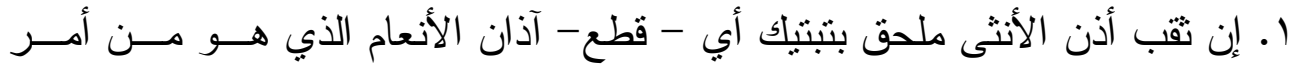

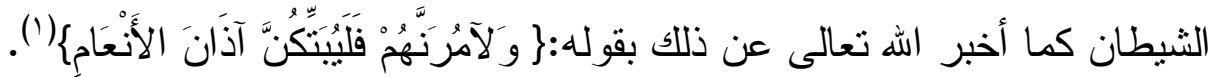

\section{واعترض على هذا الاستدلال بأن:}

إلحاق ثقب أذن الأنثى للتحلي بتبتيك آذان الأنعام قىاس مع الفارق؛ حيث إن الأصل

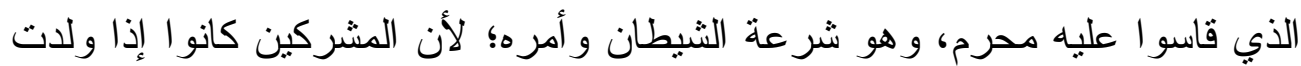
الناقة خمسة أبطن، وكان السادس ذكر ا، شقو أذن الناقة، وحرمو ا ركوبها، فثر ع لهم الثيطان ذلك شريعة من عنده(r)؛ بخلاف ثقب أذن الأنثى ففيه مصلحة شهد الثرع بجو ازها، وهي تحلي المر أة وتجملها، فحرم الأصل، وجاز الفرع(ب). r. إن في ثقب أذن الأنتى جرحا مؤلما، وتعجيل أذي بلا منفعة، وهذا لا يجوز فعله

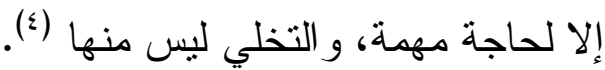
و اعترض على هذا الاستدلال:

بأنه لا يسلم عدم أهمية ثقب أذن الأنثى؛ ذلك أن فيه مصلحة مهمة للمر أة، وهي

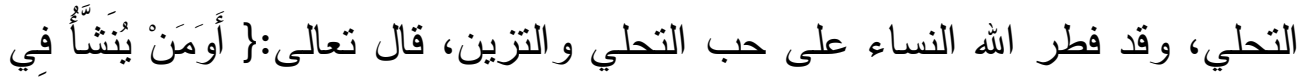

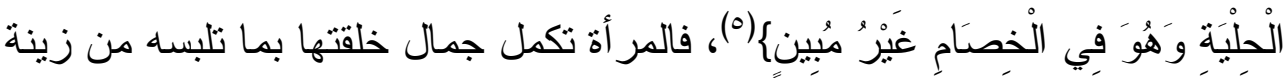

وحلية)(7)

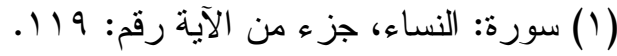

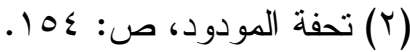

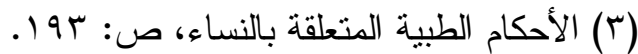

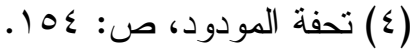

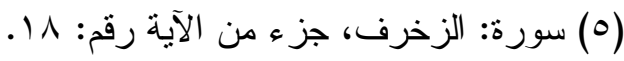

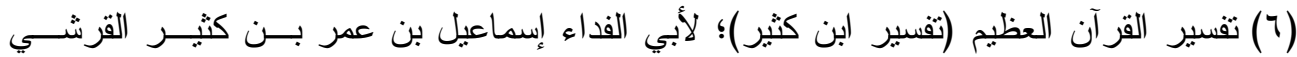

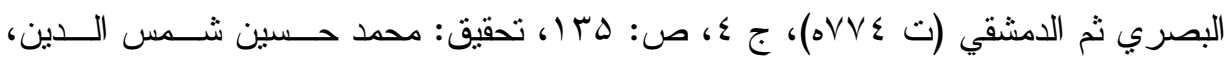

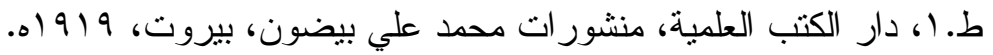


ثم إن إنكار الفائدة من ثقب الأذن للتحلي أمر مخالف للعادة، و الحس، و الأذى اليسير الذي يلحق الأنثى من جراء ثقب الأذن لا يقاس في مقابل منفعة التحلي المرجو

تحصيلها.

اعتر اض على الاستدلالات العقلية السابقة كلها:

إنه إذا سلم صحة ما ذكر من الأدلة العقلية، فإنه اجتهاد في مورد النص، ولا اجتهاد

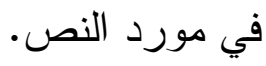

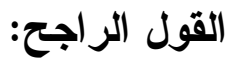

أرجح ما ذهب إليه أصحاب القول الأول القائلون بجواز ثقب أذن الأنثى للتحلي، وذللك لما بأني:

ا ـ ثبوت النصوص الثرعية المبيحة لثقب أذن الأثثى للتحلي، وسلامة دلالتها مـن الاعتر اض و المناقشة.

r. لعدم سلامة أدلة المانعين العقلية مــن الاعتـر اض و المناقـشـة، ولمعارضــتها للنصوص المثبتة للجواز r. لأن في ثقب أذن الأنثى مصلحة معتبرة شرقا، وهي التحلي. ع. لأنه ليس في ثقب أذن الأنثى مشابه للوشم، و لا تغيير لخلق الله المحـرمين، ولا مو افقة الأمر الثيطان أولياءه بتبيك آذان الأنعام. 0- لأنه ليس في ثقب أذن الأثثى ضرر يلحق بها، فجاز فعله. 7. لأنها جر احة يجوز فعلها كسائر أنو اع الجر احات، بجامع، وجود الحاجـــة فــي كل (')

(1) الأحكام الطبية المتعلقة بالنساء، لمحد خالد منصور ، ص: 19919 . 19. 


\section{المسألة الثانية}

\section{حكم ثقب أنف الأثخى للتحلي}

تقوم بعض النساء بثقب الأنف من أجل التحلي، فما حكم هذا التقب ؟ وما دليله ؟ إن ثقب أنف الأنثى التحلي بالذهب أو بالفضة أو بغيرهما جائز إذا كان من عادة

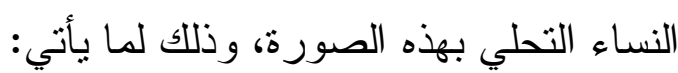
ا. قياس ثقب أنف الأنثى على ثقب أذن الأنثى، بجامع وجود الحاجة الداعية لذلك، وهي التحلي و الزينة في كل.

r. لأنه يجوز فعل هذه الجر احة كبقية أنواع الجراحات، بجامع وجود الحاجة في كل.

ب. لأنه لا يوجد في ثقب الأنف للتخلي تغيير لخلق الله تعالى. ؟. لأنه لا يترتب على فعل هذه الجر احة أذى، و لا ضرر يلحق بالأنثى. له. له.

أما إذا كان في ثقب أنف الأنتى تشبه بالكافرات، فينبغي حينئذ المنع؛ لعدم جواز التشبه بالكافر ات، ولسد الذريعة في مو افقة الكفار في بعض معتقداتهم ('). 


\section{المطلب الثاني}

\section{جراحة التجميل المحرمة (غير المشروعة)}

وهي جراحة التجميل بقد الزينة(')، ويطلق عليها أيضا: جراحة التجميل

التحسينية(؟).

و هي الجر احة التي يقصد منها: " تحسين المظهر ، وتجديد الثباب (").

و المراد بتحسين المظهر: تحقيق الثنكل الأفضل، والصورة الأجمل، دون وجود أسباب ضرورية أو حاجية تستوجب التنخل الجر احي.

و أما تجديد الثباب فهو: إز الة أثنار الهرم و الثيخوخة، فيبدو الهرم شابا فتبا(؛). وتنقسم هذه العمليات إلى قسمين: الأول: عملبات الثكل (०): ومن أمثلتها:

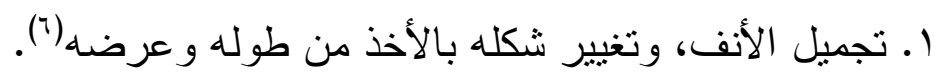
r. تجميل الذقن بتغيير شكله ليتناسب مع شكل الأنف الجديد.

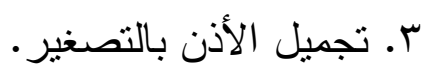

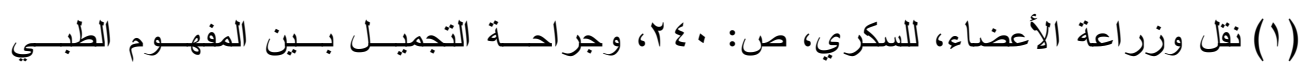

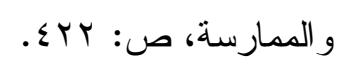

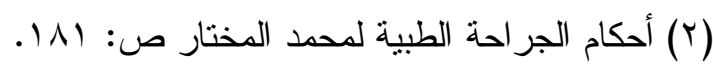

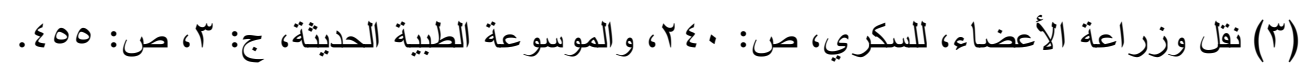

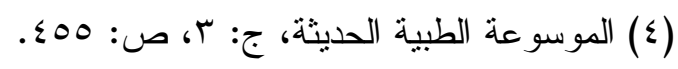

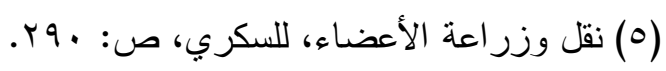

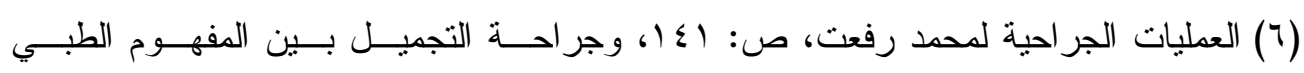

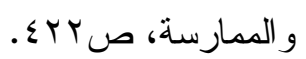




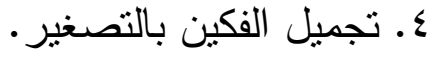

هـ تجميل الثيين بتصغير هما إذا كانا كبيرين أو العكس(').

الثاني: عمليات تجديد الثباب (؟)، ومن أمثلتها:

ا. شد تجاعيد الوجه الناتجة عن فقدان مرونة الجلد، وقلة حيوية بعض خلاياه، فتبدو ثنيات خفيفة على سطح البشرة(r).

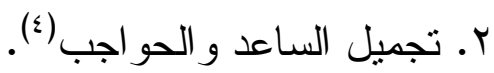

حكم جراحة التجميل المحرمة (غير المشروعة):

هذا النوع من الجراحة محرم شرعا؛ لأنه لا يشتمل على أسباب علاجية ضرورية أو حاجية؛ بل إن الغاية منه هو التجميل المحض، و العبث بالخلقة الإلهية، و التدليس، و التزوير ، و اتباع الثهو ات و الأهو اء، و الاستسلام لحبائل الثيطان و وغو ائله (0).

\section{الأدلة الشرعية الادالة على تحريم جراحة التجميل التحسينية:}

استدل على تحريم جر احة التجميل التحسينية بأدلة من الكتاب والسنة، و القياس،

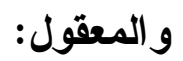

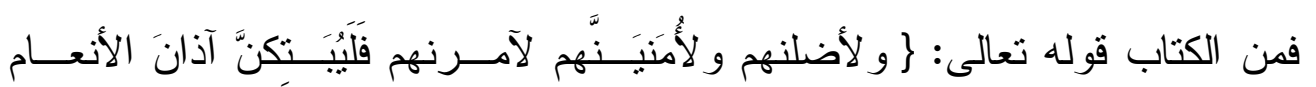

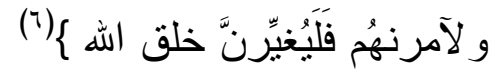

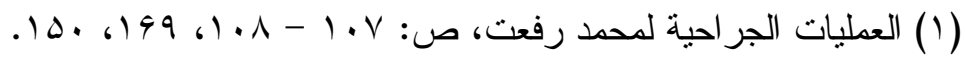

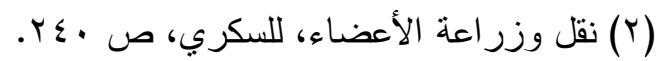

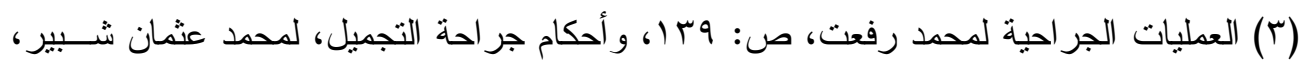
ص:

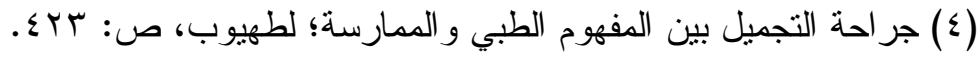

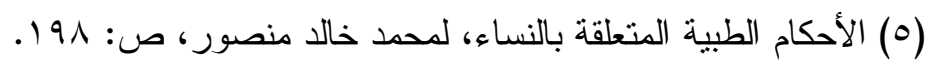

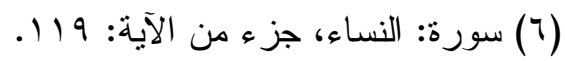




\section{جراحات التجميل}

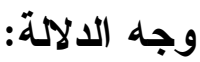

إن الآية دالة على أن تغيير خلق الله بقطع آذان الأنعام وفقء الأعين هو من المحرمات، وهو من تزيين الثيطان وغو ايته لأوليائه(')، وجر احة التجميل بقصد الزينة، كثد الوجوه و البطون، وغيره من صور التجميل داخل في النهي عن التغيير

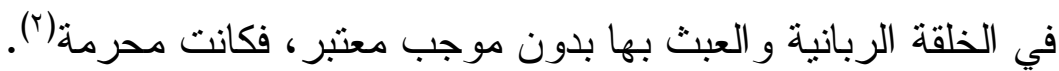

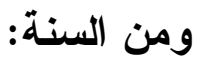

ا ـ حديث عبد الله بن مسعود أن النبي قال: العن الله الواثمات والمستوشمات

و المتتمصات ()، و المتقلجات للحسن (؛)، و المغير ات خلق الله (॰).

(1) أنو ار التنزيل وأسرار التأويل لناصر الدين أبو سعيد عبد الله بن عمر بن محمــد الـشيرازي

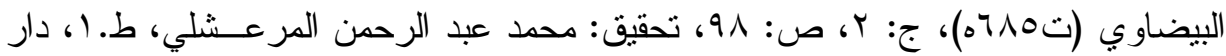

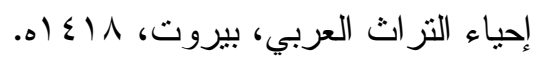

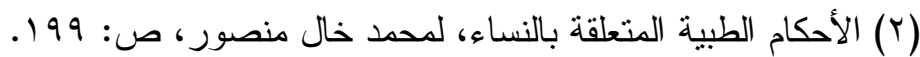
(T) النامصة: هي التي تزيل الثعر عن الوجه، و المتتمصة: التي نطلب فعل ذللك. (كتاب العـين

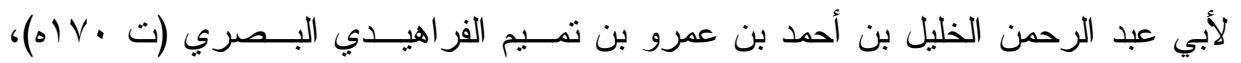

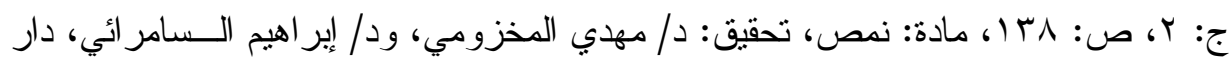
ومكتبة الهلال).

(§) المتقلجات للحسن: أي مفلجات الأسنان بأن تبرد ما بين أسنانها بين الثنايا و الرباعيات، وتفعل

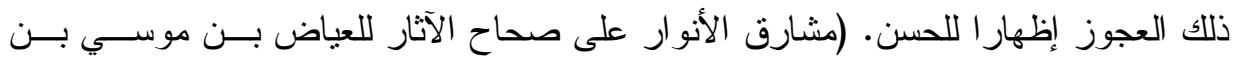

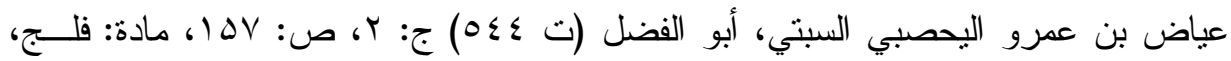
المكتبة العتيقة، ودار التزراث.

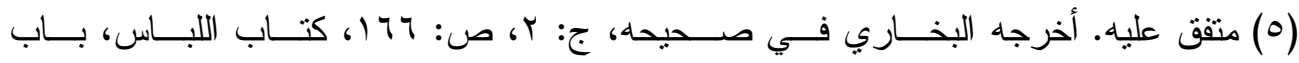

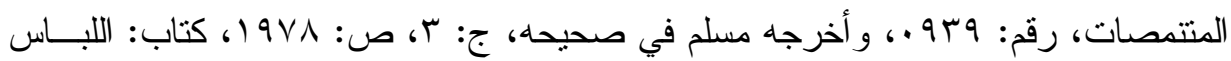

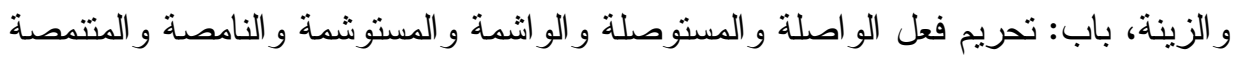

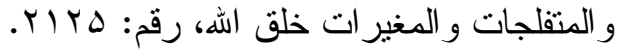




\section{جراحات التجميل}

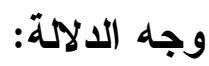

في هذا الحديث بيان عن رسول الهه أنه لا يجوز لامر أة تغيير شيء من خلقها الذي خلقها الله عليه بزيادة فيه أو نقص منه التماس التحسن به لزوج أو غيره('). فالحديث دل على لعن من فعل هذه الأشياء، و اللعن: الطرد من رحمة الله، و الطرد من رحمة الله لا يكون إلا على ارتكاب محرم، وقد علل ذلك بأنه تغيير الخلق الله، وحقيقته جمع بين طلب الحسن، وتغبير خلق الله، وهذان موجودان في جراحة التجميل بقصد الزينة والتحسين؛ لأنها تغيير لخلق الله تعالى؛ مع ابتغاء الحسن و الجمال دون وجود موجب طبي يبيح فعلها، فهي إذن داخلة في عموم اللعن، فكانت

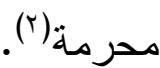

r. حديث أسامة بن شريك نه، وفيه: [ تداوو ا عباد الله، فإن الله عز وجل لم بضع

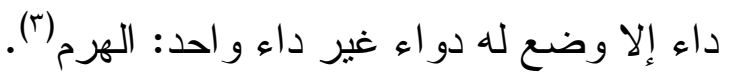

وجه الدلاهة:

إن قول النبي: [ تدووا ] فيه إثبات الطب و العلاج، وأن التداوي مباح غير مكروه؛

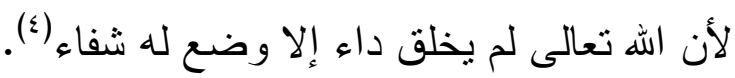

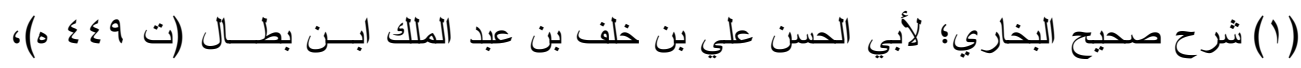

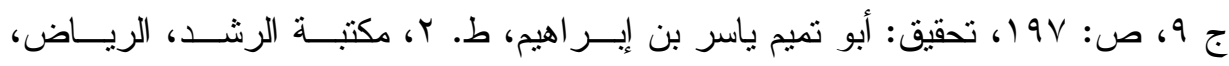

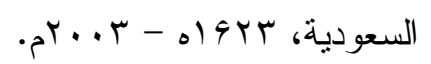

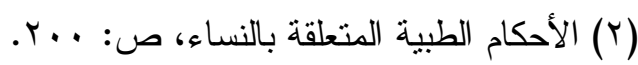

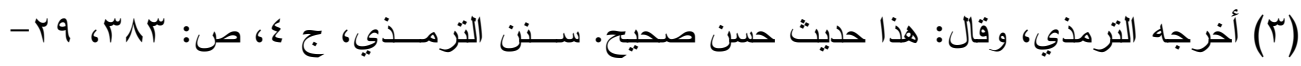

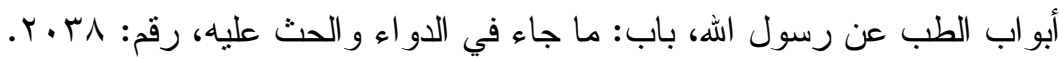

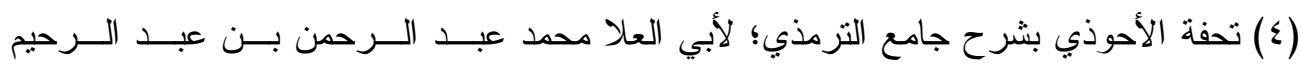

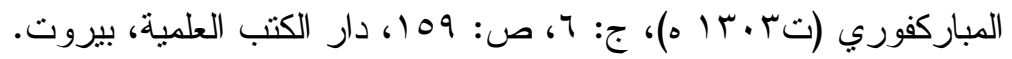


فيدل الحديث على أنه ما من داء إلا وله دواء، وهذا مشعر بجواز التداوي بشكل عام، ثم استثنى من ذلك كله داء و احد، وهو الهرم، فاستثناؤه للهرم دون سائر الأدواء يدل على عدم جواز العبث بالخلقة البشرية لإعادتها لصباها وشبابها، أو محاولة تغيير معالم كبر السن بأي وسيلة من الوسائل، وجر احة التجميل التحسينية متضمنة لذلك، فكانت محرمة.

من القياس: قياس جر احة التجميل بهدف التحسين على الوشم، و الوشر (')، والنمص بجامع تغيير الخلقة طلبا للحسن في كل.

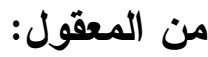

ا ـ إن هذا النوع من الجر احة فيه تزوير للحقيقة، وغش وتدليس، فكان محرما(؟). r. إنه يترنب على فعل هذا النوع من الجراحة ارتكاب لبعض المحظور ات، ومنها: أ. استخدام المخدر في هذه العمليات؛ سو اء كان عاما أو موضعيا (r)، ومعلوم أن التخدير محرم إلا لضرورة، أو حاجة معتبرة شرقا، وهذا النوع من

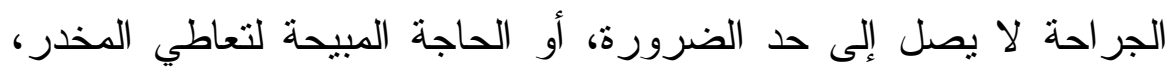
فضلا عن كون الهدف المقصود منها محرما شرقا، فيكون التخدير حينئ

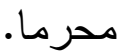

(1) الوشر : تحديد الأسنان وترقيقها بغرض الحسن. (غريب الحديث لأبي عبيد القاسم بن ســلام

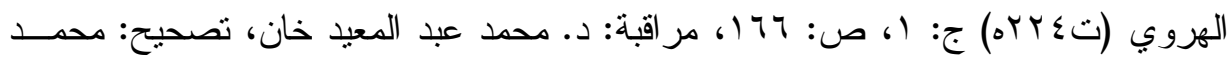

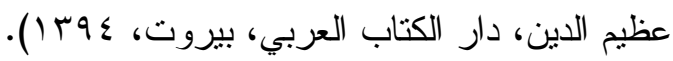

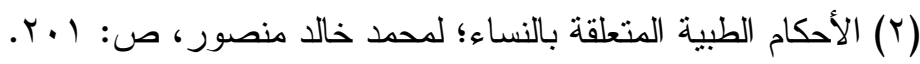

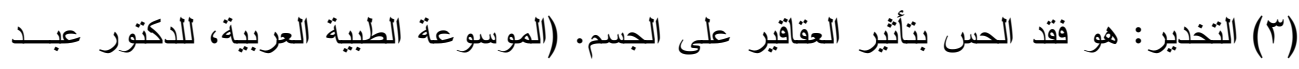

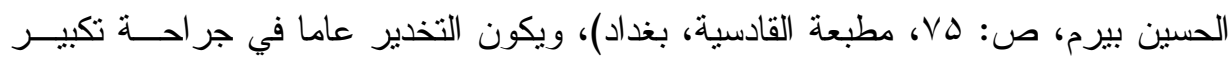

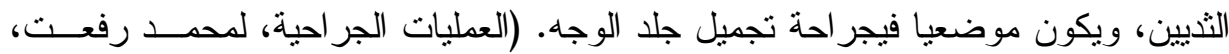

$$
\text { ص: }
$$


ب. إن فعل هذا النوع من الجراحة يؤدي إلى كثف العورة، ولمسها، ومباشرتها الغير ضرورة، ويؤدي إلى معالجة الرجال للنساء و العكس دون

ضرورة طبية، وكل ذلك فاسد شر عا (').

r. إن هذا النوع من الجراحة لا يخلو من أضرار ومضاعفات جانبية سلبية، فقد ورد في الموسوعة الطبية الحديثة ما نصه: "... فعمليات التجميل غير محققة النتائج، ومن الخير ترك الإغراق في إجرائها، أو المبالغة في التنبؤ

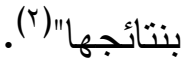

وبناء على ما تقدم من أدلة، ونظر الما تضمنه هذا النوع من الجراحة من التغيير لخلق الله، و العبث بالنفس الإنسانية، و التساهل في صيانتها، و التعدي على كر امتها؛ دون وجود حاجة طبية معتبرة، فإنه يحرم على المر أة المسلمة فعلها، أو الإقدام على تعاطيها، و أنه لا اعتبار بالوساوس و الدو افع النفسية المو هومة، فالمسلمة ترضى بما قدره الله لها من جمال المظهر والصورة، ولتعلم أن الجمال ليس مقصودا لذاته؛ بل هو لتحقيق العبودية لله عز وجل على وجه هذه الأرض، وأن ما أصابها لم يكن

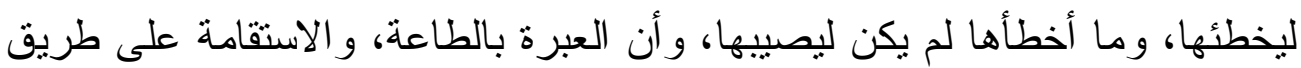
الهداية و الرشاد، ولتهرع المسلمة حينئذ لتحصيل المصالح الدنيوية و الأخروية، ولتعرض عن كل ما يؤدي بها إلى مدارك البلاء و الثقاء (r). ومن أثنهر الجر احات التجميلية المحرمة (£) المنتشرة في هذا العصر "جر احة تغيير الجنس ".

(1) أحكام الجر احة الطبية، لمحمد مختار ، ص: 110 1.

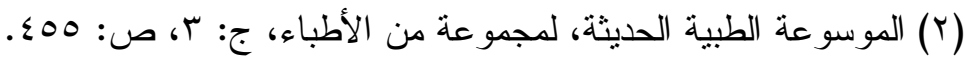

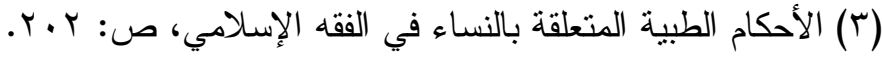

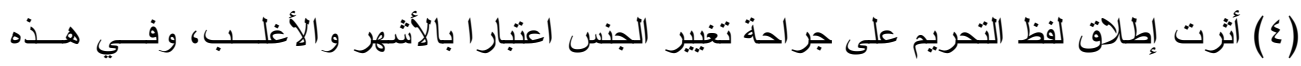

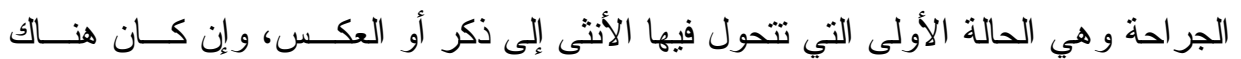




\section{حر احة تغين الحنس}

وهي الجر احة التي يقصد منها: " تغيير الأنتى إلى ذكر ".

\section{ولا تخلو هذه الجر احة من ثلاث حالات:}

الحالة الأولى: أن يتم تحويل الأنثى إلى ذكر ، وذلك باستئصسال الثذيين، و إلغاء القناة

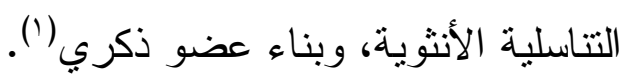

وفي هذه الحالة تخضع الأنثى التي يجري لها هذه الجراحة إلى علاج نفسي

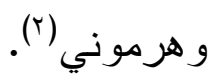

وقد وقعت عدة حوادث في الغرب، وفي مصر، تم فيها تحويل الأنثى إلى ذكر،

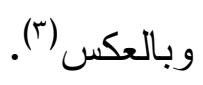

\section{حكم الثريعة في إجراء هذه الحالة من الجراحة:}

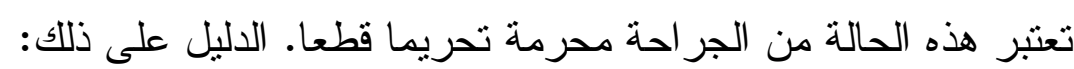
استدل على تحريم جر احة تغيير الجنس من أنثى إلى ذكر أو العكس بأدلة من

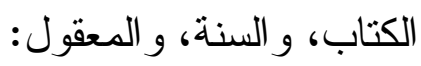

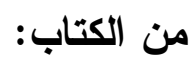

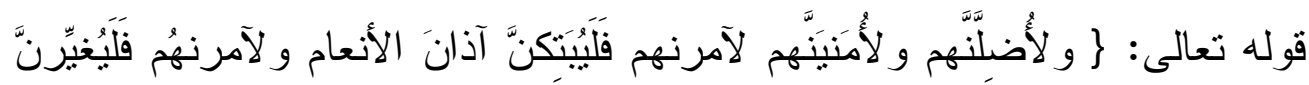

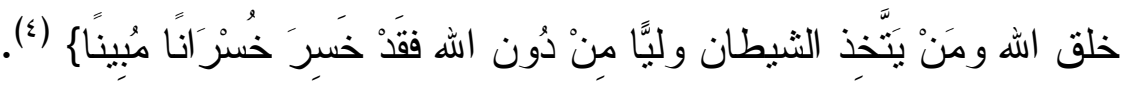

=حالتنان حكمها الجواز ، ولكن ليس في شهرة الحالة الأولى، و هذا من قبيل التوضـــــ. واله أعلم.

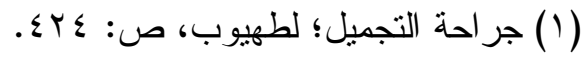

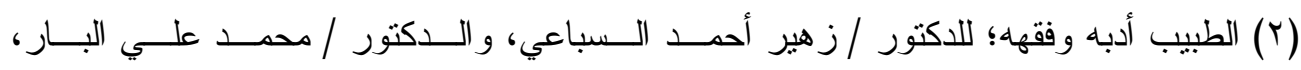

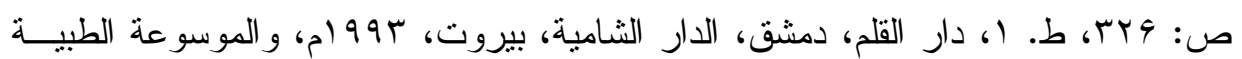

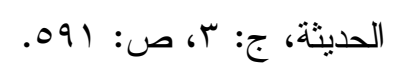

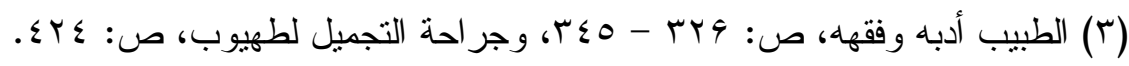
(ع) سورة النساء جزء من الآية: 911 . 


\section{جراحات التجميل}

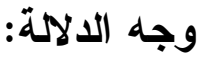

فالآية دالة على أن تغيير خلق الله بقطع آذان الأنعام، وفقء الأعين هو من المحرمات وهو من نزيين الثيطان و غو ايته لأوليائه(').

فقد تضمنت الآية الكريمة حرمة تغبير خلق الهه بدافع العبث و الثهوة، وتغيير الأنثى إلى ذكر عن طريق الجر احة باستئصال الثديين، و إلغاء القناة التناسلية الأنثوية لديها،

وبناء عضو ذكري فيه تغيير لخلق الله دون حاجة طبية معتبرة، فكانت محرمة(؟).

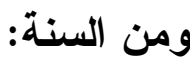
ا. حديث عبد الله بن مسعود انه قال: " لعن الله الواشمات و المستوشمات، و المتتمصات، و المتلفجات للحسن، المغير ات خلق اله "(").

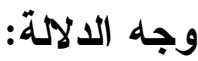

في هذا الحديث بيان عن رسول الله: أنه لا يجوز لامر أة تغيير شيء من خلقها الذي خلقها الله عليه بزيادة فيه أو نقص منه التماس التحسن به لزوج أو غيره(؛). فالحديث متضمن اللعن لمن قامت بالأفعال المتقدمة، واللعن يقتضي تحريم الفعل الملعون، وفعل هذه الجراحة فيه تغيير لخلق الله على سبيل التعدي و العبث، فكانت

محرمة (0)

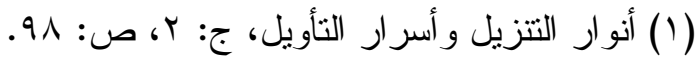

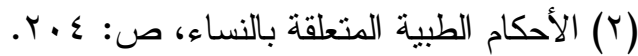

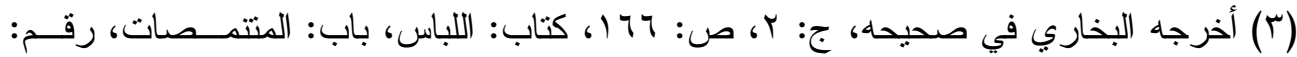

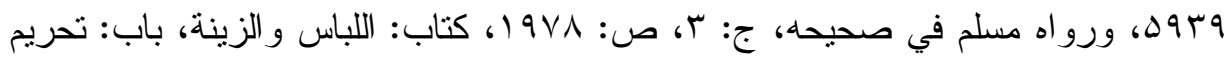

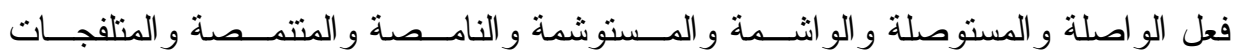
و المغير ات خلق الله.

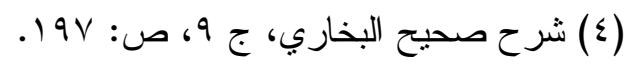

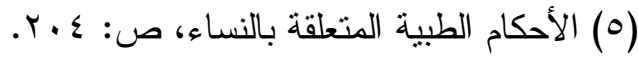


r. حديث عبد الله بن عباس رضي الله عنهما- أنه قال: "لعن رسول الله لله المنتبهين من الرجال بالنساء، و المنتبهات من النساء بالرجال "((').

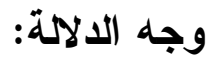

إنه لا يجوز للرجال التشبه بالنساء في اللباس و الزينة التي هي للنساء خاصة، و لا

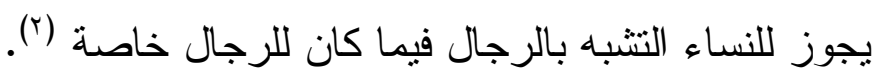
فالحديث نص في لعن من تشبه من الرجال بالنساء و العكس بأي صورة من صور التشبه، و اللعن يقتضي حرمة الأمر الملعون، وجر احة تغيير الجنس في هذه الحالة فيها نتبهه من النساء بالرجال، فكانت محرمة لدخولها في دائرة اللعن (ॅ).

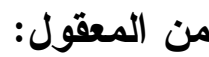
إن هذا النوع من الجر احة ترتكب فيه محظور ات شرعية، ومنها: أ. فعل الجر احة دون وجود حاجة طبية معتبرة. ب. كثف العورة، و الاطلاع عليها، ولمسها، و اطلاع الرجال على النساء و العكس؛ دون وجود موجب شرعي يبيح

وقد نص المجمع الفقهي الإسلامي بمكة المكرمة في دورته الحادية عشرة في قر اره السادس على حرمة هذا النوع من الجر احة(ْ).

(1) أخرجه البخاري في صحيحه، ج: ؟، ص: 109، كتاب: اللباس، باب: المتـشبهون بالنـساء

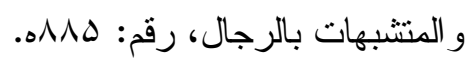

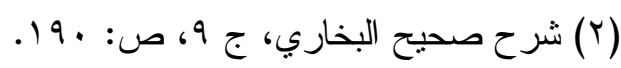

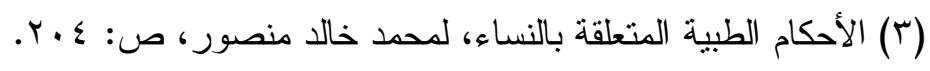

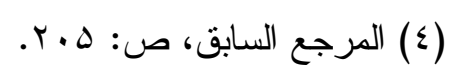

(0) قرار المجمع الفقهي الإسلامي بمكة المكرمة، الدورة الحادية عشرة، القرار الـسادس، عــام 
وهي أن ينظر الطبيب إلى الغذة التناسلية وفق فحوصات خاصة، فإن كانت الغدة مبيضا، و الأعضاء التناسلية الظاهرية ذكرية، فهي خنتى (') - أنثى كاذبة - وحينئ يتذخل جر احيا لإظهار الأعضاء النتاسلية الأنثوية الحقيقية (؟). ويحدث ذلك نتيجة إفراز هرمون الذكورة من الغدة الكظرية - فوق الكلية - فتتجه بقدرة اله الأعضاء التتاسلية الظاهرية نحو الذكورة، فينمو البظر نموا كبيرا،

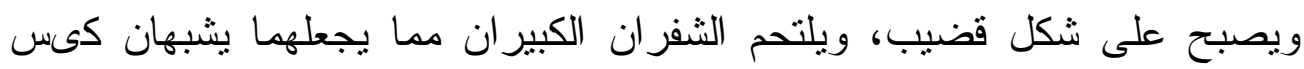
الصفن.

و الفرق بينهم أن كيس الصفن يحتوي على الخصيتين؛ بخلاف هذا فإنه يحتوي على دهى زو ائد دهنية.

(1) الخنىى: في اللغة: الذي له ما للذكر وما للأنثى. (طلبة الطلبة في الاصطلاحات الفقهية؛ لعمر

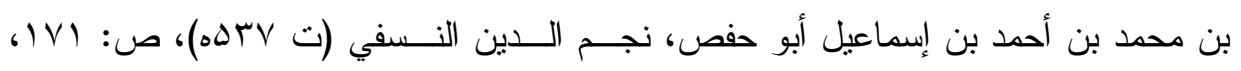

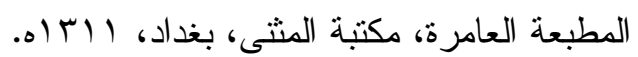

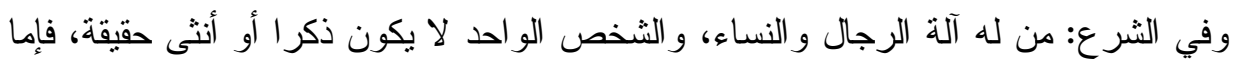

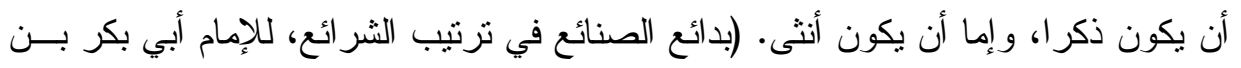

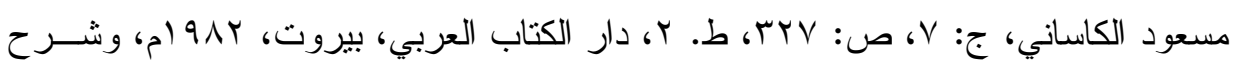

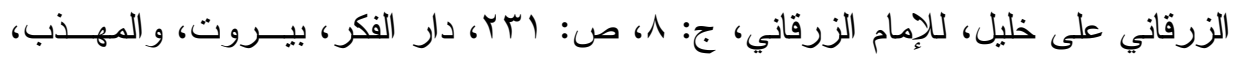

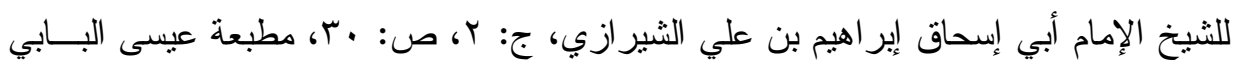

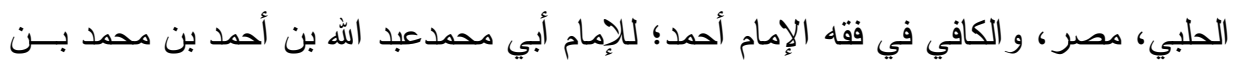

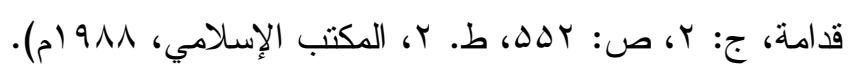

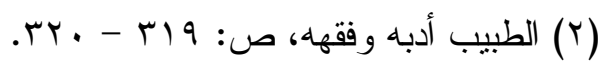


وحينما نولد الأنثى يظن أنها ذكر، ولكن سرعان ما تظهر علامات البلوغ الأنثوية، وبعد الفحص الطبي الدقيق يتبين ضرورة إجراء جر احة لإصلاح الوضع بإعادته

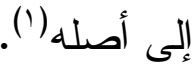

\section{الحالة الثالثة:}

أن يشتمل الجهاز التتاسلي على خصية، ومبيض، وهي ما يطلق عليه الأطباء الخنتى الحقيقية، وهي حالة نادرة الوجود، ولم يسجل الطب قيام الخنثى الحقيقية بدور مزدوج كامل مع وجود أعضاء ظاهرية؛ إما لأنثى، أو لذكر، أو الكيلهما معا، وغالبا ما تكون الغدة التتاسلية (الخصية أو المبيض) مندثرة أو هامدة.(؟).

\section{حكم إجراء جراحة تغيير الجنس في الحالة الثانية والثالثة:}

بناء على بيان الحالتين السابقتين، فهل يجوز شر عا للأطباء إجر اء منل هذه العمليات الجر احية؛ لإظهار أعضاء الأنثى الحقيقية في حالة الخنتى الأنثى الكاذبة، أو تقريب حالة الخنتى الحقيقية؛ لتمارس حياتها بصورة طبيعية بالعمل الجر احي المناسب. الجواب: إن حكم هاتين الصورتين من الجراحة الطبية جائز شرعا. و الدليل على ذلك: استدل على جواز جراحة تغيير الجنس في هاتين الحالتين بأدلة عقلية، وهي على النحو التالي:

ا. إن هاتين الصورتين تعتبران مرضا من الأمراض التي أباحت الشريعة الإسلامية معالجته بعموم الأدلة الدالة على جواز التداوي و المعالجة الطبية،

$$
\text { و الجر احة الطبية من أنواع العلاج الجائز . }
$$

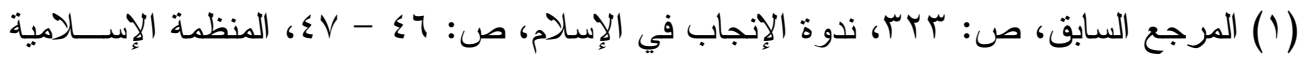

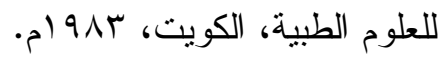

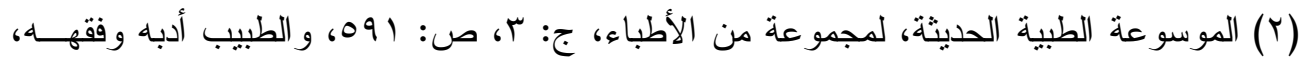
ص: פצr. 


\section{جراحات التجميل}

r. إنه يجوز فعل هذه الجر احة كما يجوز فعل غير ها من أنواع الجر احات بجامع وجود الحاجة الداعية إليها في كل.

r. إنه ليس في هذا النوع من الجر احة في هاتين الصورتين تغيير لخلق اله؛ الوجود الموجب للتذخل الجراحي، وهو وجود الحاجة، فوجب حينئذ استثناء هاتين الصورتين من النصوص الدالة على تحريم التغيير لخلق اله.

ـ. إن في بقاء هاتين الصورتين على حالتيهما ضررا بالا، ومشقة عظيمة على الأنثى، و الثربعة الإسلامية جاءت لتحصيل المصالح، ودرء المفاسد و المضار ؛

للقاعدة الفقهية القائلة: "الضرر يز ال "(')، و المشقة تجلب التيسير "(؟). ه. إنه ليس في إجر اء الجر احة في هاتين الصورتين تدليس، أو تغرير، أو تزوير ؛ لأن مقصود الجراحة هذا الرجوع إلى الخلقة الأصلية السوية بنوععلاج، فجاز

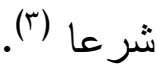

وقد نص المجمع الفقهي الإسلامي بمكة المكرمة على جواز إجراء الجراحة المناسبة بهدف إز الة الاشتباه في الأنتى لتصبح سوية كبقية النساء (ع).

(1) الأشباه و النظائر ؛ للسيوطي، ص: זم.

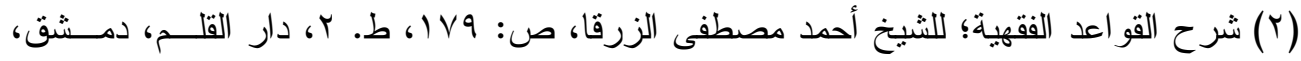
. 1919 (r) الأحكام الطبية المتعلقة بالنساء، ص: V.r. (§) قرار المجمع الفقهي الإسلامي بمكة المكرمة، الدورة الحادية عشرة، القرار الـسادس، عــام 


\section{المبحث الثاني}

\section{الضوابط والتحذيرات الواجب مر اعاتها عند إجراء الجراحات التجميلية}

أولا: الضوابط الواجب مراعاتها عند إجراء الجراحات التجميلية.

هنالك ضو ابط لابد من مر اعاتها عند إجر اء عملية التجميل؛ منها:

1. ألا تكون العملية محل نهي شرعي خاص.

r. ألا تكون العملية محل نهي شرعي عام.

r. أن تكون خاضعة للتصور الإسلامي للجمال.

ع. أن ينحقق فيها ضو ابط الأعمال الطبية عموما، وهي مر اعاة كثف العورة -

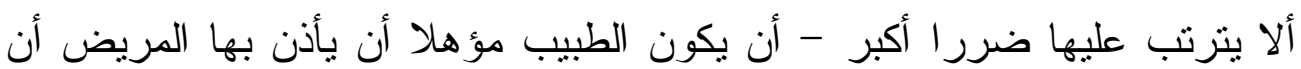
يغلب على الظن نجاحها.

ثانيا: التحذيرات الواجب مراعاتها عند إجراء الجراحات التجميلية. لابد أن تخلو الجراحات التجميلية من المحاذير الثالية:

ا ـ انتفاء القصد لتغيير خلق الله بلا ضرورة.

r. انتفاء قصد الغش و التدليس و الخداع.

r. انتفاء قصد تثبه أحد الجنسين بالآخر.

ع. انتفاء قصد النتبه بغير المسلمين.

ه. عدم استخدام النجاسات و الدحرمات في الجر احة' (1).

(1) الموسوعة الميسرة في فقه القضايا المعاصرة (قسم فقه الأسرة)، إعداد مركز التبز البحثي البحي

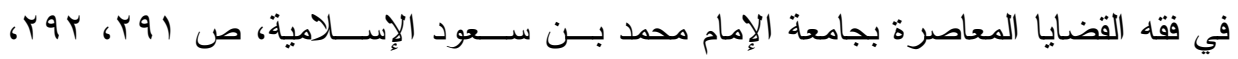

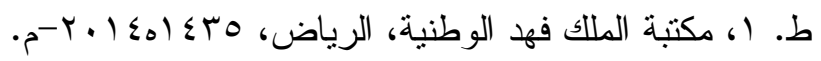




\section{الخاتمة}

الحمد لله الذي بنعمه تتم الصالحات، والصحلاة والسالم على فخر الكائنات الذي أخرج الناس من الظلمات إلى النور، وبعد..

\section{فزه أهم النتائج التي توصلت إليها من خلال البحث:}

ا ـ ضرورة البحث و الاجتهاد في المسائل الفقهية الحديثة بغية التوصل إلـى حكـم

$$
\text { الثريعة فيها. }
$$

r. إن تعلم الطب و الجر احة الطبية يعد فرضا من فروض الكفاية.

r. إن جسم الإنسان له حرمة خاصة، لا يصح للإنسان أن يتصرف في جسده بغير مسوغ شرعي، وتحريم تغيير خلق الله تعالى عما هو عليه.

ع. هنالك شروط خاصة لجواز فعل الجر احة الطبية؛ لابد من تحققها لجــواز فعـلـ

$$
\text { الجر احة مهما كان نوعها. }
$$

هـ الجر احة المشروعة هي جر احة علاجية ضرورية، أو جر احة علاجية حاجية. 7. الجر احة المحرمة هي التي لم تثوفر فيها الدو اعي المعتبرة شــر عا للتـرخيص بفعلها؛ كجر احة تغيير الجنس، و الجراحة التجميلية التحسينية التي لا تخضع إلا

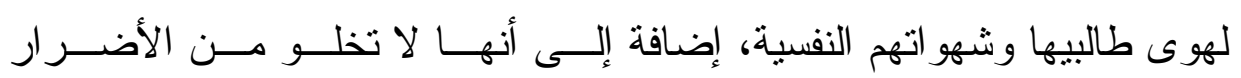
و المضاعفات، و لا ينصح الأطباء المنصفون بإجر ائها على وجه العموم، ويحرم على الأطباء فعل مثنل هذه الجر احة. 